\title{
Dressed in Myth: Mythology, Eschatology, and Performance on Late Antique Egyptian Textiles
}

Among the rich corpus of archaeological finds from late antique Egypt, today textiles tend to occupy an obscure and isolated place in scholarship. This obscurity is disappointing for several reasons, not least because of the extraordinary number of textiles that have survived, but also since the initial wave of discoveries of such textiles in the late $19^{\text {th }}$ and early $20^{\text {th }}$ centuries elicited such enormous enthusiasm and popular appreciation. The period witnessed a bumper crop of textile finds from the dry climate of the Egyptian desert. It is estimated that up to 150,000 specimens were found during this period, ${ }^{1}$ although the exact number remains impossible to determine, as fragments that originally belonged to the same piece of textile were, as per standard practice, dispersed to different museums making it very difficult to know which fragments (so-called "orphans") belong together.

The complex collecting histories and the poor archaeological documentation that the textiles come with, as well as a frustrating lack of precision in their chronology, are all important factors that have complicated scholarly attempts to place them within their proper social, religious, and historical context. Yet textiles are of major importance to our understanding of late antique social and religious life, and not least the topic of this volume, the use of mythology in late antiquity. The textiles not only constitute magnificent documents of change and continuity but also give us crucial insights into the persistence of Classical myths within a Christian environment. One of the most striking aspects of the massive corpus of Egyptian textiles is the apparent ease with which pagan and Christian motifs were produced and used simultaneously. The mythological motifs as well as other aspects of their iconography furthermore attest to cross-Mediterranean contact and cultural exchange. Nevertheless, textiles only play a minor role in scholarship outside of the specialized and frequently rather technical reports and catalogues in which they are most often presented and discussed at any length. ${ }^{2}$ An important aim of this paper is therefore to

\footnotetext{
* I would like to thank Hartmut Leppin and his team of organizers for their hospitality and interest in my work during the Frankfurt colloquium. A generous grant from the Danish Council for Independent Research's Sapere Aude career programme allowed me to complete this paper version. Many ideas for this paper were formed, developed, and substantially improved in conversation with Stine Birk. I would also like to thank Lea Stirling for reading an earlier draft, and Nils Arne Pedersen for help with Coptic. The impetus for the paper itself owes much to the pioneering work of Sabine Schrenk, Annemarie Stauffer, Henry Maguire, and Thelma Thomas.

1 As estimated by D. Thompson, Coptic Textiles in the Brooklyn Museum (Brooklyn 1971), 4-5. 2 Textiles are, for example, almost entirely absent from the recent Oxford Handbook of Roman Egypt, edited by C. Riggs (Oxford 2012), although admittedly this volume does not aim to cover
} 
bring this marginalized body of evidence more firmly into the mainstream of late antique historical scholarship.

The paper has two equal parts; the first concerns the general function and use of textiles decorated with figural images (many depicting mythical protagonists), as well as the thorny issues of chronology and the reconstruction of the physical and visual environment in which the textiles were once an integral part. This first part provides important information on the viewing context in which these textiles functioned. I will also be arguing that in order for this field of study to move forward, textiles must not be seen as exclusively decorative, daily-life objects, it is equally important to understand them as objects of performative display, self-representation, and as expressions of eschatological thinking within the funerary context. The second part focuses more explicitly on the use of mythology in late antique Egyptian textiles, such as a famous wall-hanging that is now in the Abegg-Stiftung in Switzerland (Fig. 1). ${ }^{3}$ On this extraordinary example, that is more than $2 \mathrm{~m}$ tall and roughly $1.5 \mathrm{~m}$ wide, Atalante is identified by lettering thus allowing us to identify the other figure as Meleager; it is stylistically dated to the late $4^{\text {th }}$ or early $5^{\text {th }}$ century. But what was the function of such mythological motifs, and how did pagan myths participate in the period's increasingly Christianized viewing culture?

\section{Late Antique Egyptian Textiles: Context, Chronology, and Function}

Before turning to these larger questions, it is first important to treat the issues of context, chronology, and function which are of crucial importance to assigning the textiles to their proper place in the archaeological record. The majority of the Egyptian textiles originally belonged to funerary ensembles, where they survived amazingly intact until their extraction in the late $19^{\text {th }}$ and early $20^{\text {th }}$ centuries during what has rightly been called a phase of "mummymania" across Europe. Occasionally, textiles have been found in houses, domestic or monastic dumps, but these examples are usually less well-preserved and of less interest to the themes under discussion

Late Antiquity. An accessible, recent overview of late antique Egyptian textiles can be found in T. Thomas, "Coptic and Byzantine Textiles Found in Egypt: Corpora, Collections, and Scholarly Perspectives", in: Egypt in the Byzantine World 300-700, edited by R. Bagnall (Cambridge 2007), 137162. Much of the critique raised here also resonates with T. Thomas, "Costume, Fashion and Taste in Late Antique Egypt: 'Decorative Devices' from the Textile Collection in the Kelsey Museum”, Bulletin of the University of Michigan Museums of Art and Archaeology 12 (1997-2000), 88-101.

3 S. Schrenk, Textilien des Mittelmeerraumes aus spätantiker bis frühislamischer Zeit (Riggisberg 2004), 41-45 (cat. no. 5), purchased 1966 on the German art market, claimed to have been found in Antinoopolis. H: $2.13 \mathrm{~m}$. W: $1.56 \mathrm{~m}$. Because of its exceptional quality, it has been suggested that this wall hanging was produced in a Roman workshop and exported to Egypt. 
here. ${ }^{4}$ Proper documentation of the archaeological contexts of textiles is usually entirely lacking, and when known, mostly too insubstantial for any kind of in-depth study. Although many publications have named particular sites as the provenance of individual textiles, particularly Akhmim (Panopolis) in Upper Egypt, which was one of Antiquity's most famous textile production centres, such locations should not be taken for granted, as it was during the modern antiquities trade that Akhmim became synonymous with Egyptian textiles. ${ }^{5}$ On the other hand, it is certainly true that the deserts outside Akhmim are littered with tombs that have been emptied of their contents (Fig. 2).

Other Egyptian towns provided a similarly rich harvest of textile finds. Antinoopolis in Middle Egypt is one such important site that yielded large quantities of textiles for European and American museums during early and largely undocumented excavations, as well as later episodes of looting. ${ }^{6}$ The Abegg-Stiftung's Meleager and Atalante wall-hanging (Fig. 1) is, for example, said to have been found in Antinoopolis, although its precise provenance is unverifiable. Particularly diligent in excavating at Antinoopolis was the notorious Frenchman Albert Gayet; many of the excavated textiles were dispersed to museums and private collections in North America and Europe, particularly in his home country. ${ }^{7}$ Often, individual textiles were cut into smaller pieces that could be sold to the highest bidder, thus frequently ending up in different museums. This was standard practice among excavators at the time, which has

4 A. P. Schieck, Die koptischen Textilien. Gewebe und Gewänder des ersten Jahrtausends aus Ägypten (Köln 2005), 7.

5 On the problem of Akhmim as a provenance, see Schrenk (cf. fn. 3), 15; C. Fluck, "Akhmim as a Source of Textiles", in: Christianity and Monasticism in Upper Egypt. Volume I. Akhmim and Sohag, edited by G. Gabra and H. N. Takla (Cairo 2012), 211-223; and H. Persson, "Collecting Egypt. The Textile Collection of the Victoria and Albert Museum", Journal of the History of Collections 24.1 (2012), 3-13, esp. 3-4. On the necropoleis of Akhmim, see K. P. Kuhlmann, Materialien zur Archäologie und Geschichte des Raumes von Achmim (Mainz am Rhein 1983), 50 - 86. On excavation history, see M. Erikson, Textiles in Egypt 200-1500 A. D. in Swedish Museum Collections (Göteborg 1997), 20-25; Thomas, "Textiles" (cf. fn. 2), 137-145. We have some very interesting first-hand accounts of the discovery of textiles at Akhmim by the Swiss collector-cum-antiquarian Robert Forrer (1866 -1947), whose 1895 travelogue Mein Besuch in El-Achmim (Strassburg) described the excavation of mummies wrapped in textiles, the transportation of these mummies to Cairo as well as the sale of textiles, presumably also from graves, at Luxor. Forrer's interests were immensely diverse, as he published on everything from Celtic numismatics to mammoth hunters. He named his house 'Villa Panopolitana' after the site of Panopolis/Akhmim.

6 New Italian excavations of the northern necropolis at Antinoopolis may help us contextualize these finds in the future, see H. Froschauer, "Antinoupolis. Erster Vorbericht zu den Textilfunden aus der Nekropole Nord (Grabungskampagnen Frühjahr und Herbst 2007)”, Analecta Payrologica 18-20 (2006-2008), 269-274.

7 Exact numbers are discussed in A. Geijer, "A Silk from Antinoë and the Sasanian Textile Art”, Orientalia Suecana 12 (1963), 1-36; and repeated in Erikson (cf. fn. 5), 21. On Gayet, see also N. A. Hoskins, The Coptic Tapestry Albums and the Archaeologist of Antinoé, Albert Gayet (Seattle 2004); and F. Calament, La revelation d'Antinoé par Albert Gayet (Cairo, 2 vols., 2005), and Thomas, “Textiles” (cf. fn. 2), 141-142. 
left modern scholars and conservators with a complex jigsaw puzzle to re-assemble. In some cases, fragments of the same textiles have ended up in collections divided across as many as two continents and seven countries. ${ }^{8}$ In the public presentation of his work, Gayet thrived on the shock value that these partly mummified bodies offered to fin-de-siècle Parisian audiences. ${ }^{9}$

Because of this chequered excavation history, the precise find-spots of individual textiles are rarely known, and even more rarely can the textiles be connected with architecture and other finds that would have been part of a complete, funerary ensemble, which makes it extremely difficult to reconstruct their role within the larger context of funerary archaeology and burial rituals. ${ }^{10}$ However, recent years have seen important work in museum archaeology - that is in tracing the collecting histories and the often doubtful find-spots assigned to textiles in the $19^{\text {th }}$ and early $20^{\text {th }}$ century and then, when possible, to reconstruct the contexts in which they were found, based on notebooks and the correspondence between excavators and the museums who funded their work or acquired finds. ${ }^{11}$ Newer excavations have furthermore introduced more specialized scientific methods to record and preserve wrapped bodies, providing much valuable information in the process. ${ }^{12}$

In those relatively rare cases where we are familiar with the archaeological context, it is clear that the dead were placed in shallow graves at a depth of roughly $1.5 \mathrm{~m}$, sometimes built up with bricks (Fig. 3). ${ }^{13}$ These graves were most frequently simple pits that in some cases were defined at the bottom by a wooden board, but

8 Schrenk (cf. fn. 3), 175, cat. no. 58.

9 D. Montserrat, "Unidentified Human Remains: The Erotics of Biography”, in: Changing Bodies, Changing Meanings. Studies on the Human Body in Antiquity, edited by D. Montserrat (London 1998), 162-197; and N. Cox, "La mort posthume: Maurice Heine and the poetics of decay", Art History 23.3 (2000), 417-449.

10 F. Dunand, "Between Tradition and Innovation: Egyptian Funerary Practices in Late Antiquity”, in: Egypt in the Byzantine World, edited by R. Bagnall (Cambridge 2007), 163-184, discusses late antique Egyptian funerary practices, but does not deal with the significance of textiles in any detail. On Roman-period funerary religion in Egypt, see C. Riggs, The Beautiful Burial in Roman Egypt: Art, Identity, and Funerary Religion (Oxford 2001), and now M. A. Stadler, "Funerary Religion. The Final Phase of an Egyptian Tradition", in: Oxford Handbook of Roman Egypt, edited by C. Riggs (Oxford 2012), 383-397.

11 Important contributions to this field are the individual contributions to S. Schrenk (ed.), Textiles in situ. Their Find Spots in Egypt and Neighbouring Countries in the First Millennium CE (Riggisberg 2006). See also Persson (cf. fn. 5) on the case of the Victoria \& Albert Museum.

12 E. Cortes, "Recovering Contexts: The Roman Mummies Excavated by The Metropolitan Museum of Art at Dahshur, Egypt”, in: Dressing the Dead in Classical Antiquity, edited by M. Carroll and J. P. Wild (Stroud 2012), 75-88. On the reconstruction of contexts for textiles, see also N. Kajitani, “Textiles and Their Context in the Third- to Fourth-Century CE Cemetery of al-Bagawat, Khargah Oasis, Egypt, from the 1907-1931 Excavations by The Metropolitan Museum of Art, New York”, in: Textiles in situ. Their Find Spots in Egypt and Neighbouring Countries in the First Millennium CE, edited by S. Schrenk (Riggisberg, 2006), 95-112.

13 Kuhlmann (cf. fn. 5), 62 (with a reconstruction of one such grave found at Achmim); Erikson (cf. fn. 5), 21. 
only very rarely included a coffin. Such burial grounds were often used over a very long time, and sometimes bodies were piled on top of each other in up to 10 to 15 layers, which, if better documented, would have allowed us to more closely understand the nature of such continuities of both place and practice. The bodies themselves seem to have been wrapped in numerous layers of textiles. Occasionally, adorned textiles also functioned as cushions to support the head and the feet of the deceased. ${ }^{14}$

It is often assumed in scholarship that the practice of wrapping bodies in textile replaced proper mummification and that this change in burial rites was a consequence of the process of Christianization, thus reflecting new, Christian conceptions of the body and its place in the afterlife. ${ }^{15}$ However, this is questionable since some cases of mummification can be dated to well after the $4^{\text {th }}$ century. ${ }^{16}$ It has also been shown that Christian and pagan tombs were often located close to each other and within the same burial grounds, for example, in the case of Bagawat, suggesting that much previous work has over-emphasized the extent to which burial traditions can be classified according to religious differences. ${ }^{17}$ Identifying religious affiliation based exclusively on the textile finds thus remains a fundamental problem, and one needs to be very careful when assigning a grave to either a pagan or a Christian occupant. This issue is, of course, of great importance to how we interpret the use and function of mythological motifs on textiles found in tombs, but is greatly hindered by insufficient archaeological documentation.

Another problematic issue that concerns the study of the textiles is chronology. Dating of the textiles beyond stylistic measures remains extremely difficult and has not made further exploration any easier. Among the 35,000 pieces of textiles known to Pierre du Bourguet when he published his fundamental catalogue of parts of the Louvre collection in 1964, only one could be placed within a relative chronology based on non-stylistic criteria. ${ }^{18}$ To that may be added the so-called Aurelius Collu-

14 Such as in the well-known case of Euphémiâan in Brussels, see now A. P. Schieck, "Late Roman Cushions and the Principles of Their Decoration", in: Clothing the House. Furnishing Textiles of the $1^{\text {st }}$ Millennium AD from Egypt and Neighbouring Countries. Proceedings of the $5^{\text {th }}$ Conference of the Research Group ‘Textiles from the Nile Valley', Antwerp, 6-7 October 2007, edited by A. De Moor and C. Fluck (Tielt 2009), 115-131.

15 V. Gervers, "Medieval Garments in the Mediterranean World”, in: Cloth and Clothing in Medieval Europe. Essays in Memory of Professor E. M. Carus-Wilson, edited by N. B. Harte and K. G. Ponting (London 1983), 279-315, esp. 280; and Erikson (cf. fn. 5), 21, but see remarks in Dunand (cf. fn. 10). More generally on Coptic attitudes towards the body as observed through textual evidence, see G. Fischhaber, Mumifizierung im koptischen Ägypten. Körperlichkeit im 1. Jahrtausend n. Chr. (Wiesbaden 1997).

16 G. Gabra and M. Eaton-Krauss, The Treasures of Coptic Art in the Coptic Museum and Churches of Old Cairo (Cairo 2006), 170.

17 Dunand (cf. fn. 10), 163 and 179.

18 P. de Bourguet, Musée National du Louvre. Catalogue des Étoffes Coptes I (Paris 1964), 17-21; and see A. Lorquin, Les tissues coptes au musée national du Moyen Age - Thermes de Cluny (Paris 1992), 
thus and Tisoia cloth that was found by Gayet at Antinoopolis and which is now in Brussels. It was discovered in a grave alongside a will, giving us the names of the two individuals that are portrayed within the arcades of the upper part of this cloth, as well as a date around 454-456, thus providing us with a terminus post quem for the deposition of the grave and a likely date for the fabrication of its textiles within the third quarter of the $5^{\text {th }}$ century. The grave is also exceptional for being the only burial excavated by Gayet that contained a coffin. Many other textiles are in publications given a broad $4^{\text {th }}$ - to $6^{\text {th }}$-century date, based on stylistic criteria - but, of course, when addressing questions of religious change and continuity, it makes quite a difference whether a motif belongs to the $4^{\text {th }}$ or to the $6^{\text {th }}$ century, as the social context in which they functioned might have changed dramatically. Recent advances in radiocarbon dating have yet to aid progress, at least for our purposes, as they give relatively broad dates covering several centuries. ${ }^{19}$

Putting the issue of chronology aside, we can look at the use and function of the textiles that were found in these late antique graves. Several different types of clothing but also wall hangings and mattress coverings were used to wrap the bodies of the deceased or to cover funerary beds, but the most common type of garment was the tunic that very often had been previously worn, which is clear from the evidence of both wear and tear as well as repairs. ${ }^{20}$ Other items, such as burial shrouds, were deliberately made for the funerary context and do not bear any signs of previous use. Fig. 4 shows three quite standard variations of the tunic; the central one is the most simple with just a few rectangular fields for decoration and oblong bands on the sleeves. To the left and to the right are two elaborate examples that both have a set of clavi running down the middle as well as four orbiculi, covering the knees and the shoulders. Men and women wore the same kinds of garments, ${ }^{21}$ making it very difficult to detect potential gender preferences in choice of iconography and decoration, although in some cases it may be speculated whether particular images

11. For a good overview of the problems of dating, see F. Pritchard, Clothing Culture. Dress in Egypt in the First Millennium AD. Clothing from Egypt in the Whitworth Art Gallery, The University of Manchester (Manchester 2006), 13-25. Another chronological fix point comes from an undisturbed child's grave excavated by Petrie at Hawara in the Fayum. The grave contained textile fragments as well as toys, lamps, footwear, and, most significantly, a coin of a son of Constantine I dated to c. 340, now in the Ashmolean. This coin allows us to date the textiles to around the middle of the $4^{\text {th }}$ century, but they unfortunately do not include figural representations and are thus of relatively little comparative value for the purposes of the present study. On Greek, Roman and Byzantine tombs at Hawara, see now I. Uytterhoven, Hawara in the Graeco-Roman Period. Life and Death in a Fayum Village (Leuven 2009). The tomb in question is her Grave Context no. 34 (ibid., 203). On scientific dating methods, see Egyptiennes. Etoffes coptes du Nil, edited by M.-C. Bruwier (Mariemont 1997), 107-116.

19 For an overview of radiocarbon-dated textiles in the Abegg-Stiftung, see Schrenk (cf. fn. 3), 476478.

20 For the evidence from Bagawat, see Kajitani (cf. fn. 12), 103. Here, adult garments had been preworn, whereas children's tunics had not. On burial shrouds from Bagawat, see ibid., 106-107.

21 Also clear from the better documented excavations of Bagawat: Kajitani (cf. fn. 12), 103. 
were chosen because they were appropriate to the sex, age, or life experiences of the wearer.

From surviving papyri, we get a sense of the issues of patronage and personal choice that were responsible for the layout of textiles. The papyri inform us that customers had a considerable degree of freedom to choose particular motifs and desired forms of decoration, leaving room for individual specifications to be made. ${ }^{22}$ It is usually assumed that consumers were able to choose from a variety of standard motifs in somewhat elusive pattern-books, almost as if browsing through a mail order catalogue. So in that sense, these textiles allowed for individual messages to be communicated and could as such be used as a medium to express social and religious identity. This observation resonates well with other evidence that suggests that decorum was an important aspect of everyday dress in Roman Egypt. ${ }^{23}$ It may furthermore be fruitful to see these textiles as part of a middle-class culture which has its own aesthetic sensibilities, in reference to Emanuel Meyer's recent book on urban life and aesthetics in the Roman world. ${ }^{24}$

The overall design of tunics allowed for various kinds of ostentatious display, not least through elaborate and colourful figural representations on the orbiculi. The design of the tunics also allowed for further forms of displaying wealth, even to the extent that jewellery could be mimicked through a variety of representational devices. Fig. 5 shows a fragment of a tunic, probably dating to the $4^{\text {th }}$ century and now in Boston, which on both sides of the collar is decorated with imitations of precious stones and gold. ${ }^{25}$ A representation of Dionysos finding the sleeping Ariadne (both figures are identified in Greek) decorates the lower orbiculus of the same garment. The other orbiculus shows a single bust of Dionysos. A $6^{\text {th }}$-century example shows very nicely how pagan motifs, the heavily stylized sea monsters or nereids on the clavi and the nude dancing figure, could co-exist with Christian symbols, such as a prominent cross, which clearly imitates an actual, hanging cross (Fig. 6). ${ }^{26}$ Such

22 E. Wipszycka, “Textiles, Coptic: Organization of Production”, in: The Coptic Encyclopedia, vol. 7, edited by A. S. Atiya (New York 1991), 2218-2221, esp. 2220, and see Thomas, "Costume" (cf. fn. 2), 95-96. M. Cannata, "Funerary Artists. The Textual Evidence”, in: Oxford Handbook of Roman Egypt, edited by C. Riggs (Oxford 2012), 597-612, concludes that during the Roman period, Egyptian artists and artisans were generally not specialized in producing for the funerary market. It is very likely that the same is true for later textile production, making it even more difficult to distinguish between 'domestic' and 'funerary' production.

23 Thomas, "Costume" (cf. fn. 2), 94.

24 E. Mayer, The Ancient Middle Classes. Urban Life and Aesthetics in the Roman Empire 100 BCE 250 CE (Cambridge, MA 2012).

25 Boston, Museum of Fine Arts, inv. 46.402, purchased 1946 in Paris; see Age of Spirituality. Late Antique and Early Christian Art, Third to Seventh Century, edited by K. Weitzmann (New York 1979), 146-147 with a further example of the imitation of jewellery; LIMC, Dionysos (in peripheria orientalia), no. 112 .

26 Brooklyn Museum, acc. no. 38.753, see Thompson (cf. fn. 1), 82-83. 
playful representations are testimony to the creative ambitions of the Egyptian textile makers.

Although we need to be aware that the textiles found in the graves cannot simply be seen as accurate reflections of the everyday appearance of late antique Egyptians, ${ }^{27}$ some observations on the performative character of the textiles can be made. Recent research on Roman dress has indeed stressed the performative value of textiles in different contexts. The presence or lack of clavi had for long been used to denote status and rank on the Roman toga, a tradition which is continued on these tunics through the use of very elaborate examples. ${ }^{28}$ Some tunics could also be quite bulky, emphasizing not the actual size of the wearer but his or her physical stature. The performative value of the textiles is furthermore emphasized by their rich use of vivid colours (including occasionally the use of gold thread) and lavish, tactile materials.

It can furthermore be argued that the textiles served as objects of movable performative display that in various ways mirrored the reality of human experiences and rituals. ${ }^{29}$ This is perhaps most striking in the case of the many textiles that represent dancing figures and that have recently been studied by Elisabeth Lässig. ${ }^{30}$ One example, dating to the $6^{\text {th }}$-century and now in Gothenburg, depicts dancing figures within the architectural setting of an arcade (Fig. 7). ${ }^{31}$ Such garments may very well have been worn during such occasions with the representation of maenads and satyrs deliberately juxtaposed with the performance of real-life ritual. They have consequently sometimes been referred to as festival or ritual garments.

Textiles have generally been regarded as objects of daily life, and, of course, in a general sense, that is very much what they are (and those that have been uncovered in domestic contexts, such as Karanis in the Fayum or Kellis in the Dakhla, obviously were). They allow us to come close to the people who wore them in their everyday routines. Yet they also hold significance beyond daily life, not least because of the funerary context in which the majority of them have been found. However, in spite of the fact that most of the textiles come from graves, little attention has been paid to their funerary significance and the potential meanings that they may have

27 Thomas, "Costume" (cf. fn. 2), 93-94.

28 S. Stone, "The Toga: From National to Ceremonial Costume", in: The World of Roman Costume, edited by J. L. Sebesta and L. Bonfante (Madison, WI 2001), 13-45, esp. 15. On use, see also M. Rassart-Debergh, Textiles d'Antinoé (Egypte) en Haute-Alsace. Donation E. Guimet (Colmar 1997), 100 105. For a recent study focusing on the performative value of Byzantine textiles in the liturgical context, see W. T. Woodfin, The Embodied Icon. Liturgical Vestments and Sacramental Power in Byzantium (Oxford 2012).

29 See also S. Davis, Coptic Christology in Practice. Incarnation and Divine Participation in Late Antique and Medieval Egypt (Oxford 2008), 165-170.

30 E. Lässig, “Tanz auf spätantiken Textilien aus Ägypten”, Mitteilungen zur christlichen Archäologie 17 (2011), 51-76.

31 Erikson (cf. fn. 5), 104-106, cat. no. 5. Further contemporary examples, now in the Louvre, similarly depict dancing figures within an arcade, see Bourguet (cf. fn. 18), 96-97, nos. C 32, and C 33, from the Fayum. 
had within that context. On a general level, the funerary significance of textiles is noted in a will, dated to 723: "When I leave my body, it will be above all your duty to take care of the clothing of my body and of my sacred offering." 32 Although mummification on the whole may have been on the decline, the several layers of textile wrappings that were often used demonstrate a continued interest in keeping the body intact as a whole, a sentiment which is reflected in the quote. The multiple layers of textile constituted a container for the body, similar to the function of a sarcophagus; a point that may also help to explain the overall lack of coffins in these Egyptian tombs.

In light of their funerary context, the textiles' dancing scenes may have held a particular meaning by signifying a general sense of joie-de-vivre and aspirations for a pleasant afterlife, perhaps even in the company of Dionysos. The textiles were thus meaningful objects in both life and death, and their meaning was very much dependent on the context in which they were used (and indeed re-used). This means that within the funerary context, the mythological scenes would have functioned as bearers of meaning in themselves. The funerary significance of the textiles becomes especially clear when we compare their iconography with other media, such as Egyptian funerary architecture from the same period, as well as evidence from other parts of the Mediterranean, notably sarcophagi, one of the main funerary arts in the city of Rome, Greece, and Asia Minor during the imperial period. ${ }^{33}$ Images of abundance seemingly had a particular significance within this context, both on Roman sarcophagi and on Egyptian textiles. ${ }^{34}$ The popularity of sea nymphs, either as a framing device or as the centre piece of decoration, for example in the case of two $6^{\text {th }}$-century medallions in the Louvre, is furthermore unlikely to be a coincidence in both of these media, again reflecting aspirations for a pleasant afterlife (Figs. 8a b).$^{35}$ Consideration of specific iconographies may strengthen this argument, especially when applying a cross-media approach. So, for instance, there is a tendency to regard hunt scenes as a theme linked to the imperial cult and virtus, ${ }^{36}$ although much of this finds direct parallel in funerary arts in the city of Rome where it does not seem

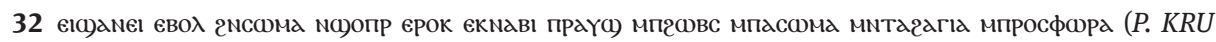
68.64-6, translation quoted from Dunand [cf. fn. 10], 180).

33 P. Zanker and B. C. Ewald, Mit Mythen leben. Die Bilderwelt der römischen Sarkophage (München 2004).

34 For a particularly magnificent example, see Au fil de Nil. Couleurs de l'Égypte chrétienne, edited by J. Santrot et al. (Paris 2001), 119.

35 Bourguet (cf. fn. 18), 98, cat. no. C 36, inv. nos. X 4339 and X 4311. For an $8^{\text {th }}$-century example, see ibid., 192, cat. no. E19. Nereids are also depicted in $5^{\text {th }}$-century architectural sculpture from Egypt, see Ägypten. Schätze aus dem Wüstensand. Kunst und Kultur der Christen am Nil, edited by M. von Falck and F. Lichtwark (Wiesbaden 1996), 83, cat. no. 16.

36 E.g. Y. Bourgon-Amir, Les tapisseries coptes du Musée Historique des Tissus, Lyon (Montpellier 1994), $29-37$. 
to have had that direct meaning, but rather been used as a means of expressing particular aspects of the deceased individuals' identity. ${ }^{37}$

The same point can be made regarding the use of portraits on Egyptian textiles. ${ }^{38}$ A particularly splendid example, now in the Louvre, was found in Antinoopolis, and is dated to the $6^{\text {th }}$ century (Fig. 9).$^{39}$ In the centre, we see a medallion portrait of a woman who wears a diadem set with polychrome stones in her hair, alluding to high status and prestige. Such portraits have a strongly heroizing or even divinizing function which is underlined here by the inclusion of a nimbus in the background. The medallion is placed within a square frame that is filled by four naked nereids, riding on sea monsters and here used as a framing device, as well as a variety of different fish. This fragment is testimony to a deeply traditional iconography that is also found on Roman funerary monuments, and again sarcophagi in particular, where portrait medallions are frequently supported by sea monsters or nereids. These socalled Meerthiasoi have by several scholars, notably Paul Zanker, been interpreted as a particular Glücksvision appropriate for the allusions to the afterlife. ${ }^{40}$ Another splendid example of a portrait on a tabula is now in Lyon and has been dated to the $5^{\text {th }}$ or $6^{\text {th }}$ century. ${ }^{41}$ This is one of a set of three that originally adorned a tunic. A woman is portrayed in the central square with a laurel branch in her hair, an attribute that again serves to conjure up divine or heroic associations to the viewer. Such portraits are not only testimony to the flourishing of the portrait arts at a time when this genre was in steady decline in round sculpture, but also suggest that there was a rich funerary tradition in which textile portraits of the deceased served to commemorate and heroize those buried in them..$^{42}$ Yet unlike mummy portraits that have received a veritable surge of scholarly interest in the last 30 years or so, these funerary portraits have been largely overlooked.

\section{Mythological Themes on Late Antique Egyptian Textiles}

This second part focuses explicitly on the role of the mythological motifs that decorated late antique Egyptian textiles, while keeping in mind the previous remarks on their context and function within the funerary sphere. The motifs are entirely drawn

37 S. Birk, Depicting the Dead. Self-Representation and Commemoration on Roman Sarcophagi with Portraits (Aarhus 2013), 108-109.

38 For an overview of the Egyptian portrait tradition, see now B. Borg, "Portraits", in: Oxford Handbook of Roman Egypt, edited by C. Riggs (Oxford 2012), 613-629.

39 Louvre, inv. AF 5472; Bourguet (cf. fn. 18), cat. no. C 77; Santrot et al. (cf. fn. 34), 124, cat. no. 87. 40 Zanker and Ewald (cf. fn. 33), 117-134.

41 Lyon, Musée des Tissus de Lyon, inv. 29215, purchased in 1910, and see Santrot et al. (cf. fn. 34), 88 , cat. no. 58 .

42 Cf. the vitality of the North African mosaic portrait tradition into Late Antiquity. 
from the repertoire of Classical (rather than Egyptian) myths, a fact that may help us to understand the cultural context in which they were produced and viewed. Large-scale mythological scenes, especially the most spectacular examples, such as the so-called Dionysiac wall-hanging in the Abegg-Stiftung that, following reconstruction, appears to have been $2 \mathrm{~m}$ tall and at least $7 \mathrm{~m}$ wide, have by far attracted the most attention in art historical scholarship. ${ }^{43}$ The original display context of this work of art is entirely lost to us, but the wall-hanging itself certainly attests to the continued interest in the world of Dionysos and his followers into the $4^{\text {th }}$ century. But what form of continuity do these mythological scenes attest to - paganism, paideia, or tradition in terms of aesthetics and literary culture?

There are a wide variety of mythological representations on Egyptian textiles, and in the following I will be necessarily selective and focus on some examples that I find particularly useful for shedding light on the function of mythology within particular contexts. Generally, one can divide the mythological motifs into two broad categories; narrative scenes with interacting figures within the same frame and single-figure scenes where the protagonist does not interact with other figures, although these may belong to a larger iconographic programme or series. First I will discuss the single-figure scenes that in fact constitute the largest group and appear to have offered the opportunity to express aspirations for the afterlife as well as other aspects of religious and social identity.

Iconographic connections between such single-figure representations can be confidently established in a number of cases, providing a sense of the way in which the decoration of the textiles was conceived and executed. ${ }^{44}$ Two examples from Russian collections demonstrate this. A personification of the Nile, identified by lettering and dated to the $3^{\text {rd }}$ or $4^{\text {th }}$ century, is now in Moscow's Pushkin Museum (Fig. 10). ${ }^{45}$ The Nile is here shown with a cornucopia emphasizing the aspect of abundance; this is a popular theme on Egyptian textiles, which is unsurprising given the river's local significance and symbolism. The continuous cycle of the flooding of the Nile furthermore provided a suitable metaphor for life, death, and re-birth to many Egyptians, and it can also be observed in late antique architectural sculpture in other funerary settings. Another medallion, which originally adorned the same tunic and is now on display in St Petersburg, emphasizes this aspect (Fig. 11). ${ }^{46}$ The St Petersburg

43 Schrenk (cf. fn. 3), 26-34, cat. no. 1, acquired 1986 on the German art market.

44 I have explored elsewhere the idea that single-figures on tunics could function as markers of religious identity (T. M. Kristensen, "Textiles, Tattoos and the Representation of Pilgrimage in the Roman and Early Christian Periods”, HEROM - Journal on Hellenistic and Roman Material Culture 1 [2012], 107-134, esp. 123-124).

45 Pushkin Museum, Moscow, see von Falck and Lichtwark (cf. fn. 35), 308-309, cat. no. 349. On the iconographic significance of the Nile in Late Antiquity, refer to T. Thomas, Late Antique Egyptian Funerary Sculpture. Images for This World and for the Next (Ann Arbor, MI 2000), 63-64.

46 Hermitage Museum, St Petersburg, see von Falck and Lichtwark (cf. fn. 35), 307, cat. no. 348. On the iconography of Ge in the Egyptian funerary context, see Thomas (cf. fn. 45), 64-65. 
medallion depicts the earth goddess Ge, here again identified by lettering and framed by a similar floral circular band as the Nile roundel, which suggests that they were made by the same workshop and thus belong together. The themes that connect these two singular representations are fertility and the cycle of life and death, which both would have been particularly apt in the funerary context, constituting a coherent iconography by means of the juxtaposition of different mythological figures and personifications. As such, the pair expressed a coherent eschatological whole.

Seasonal personifications seemingly attest to a similar form of iconographic coherency, and tunics could be adorned with depictions of the seasons such as winter (keimerini) and spring (earini), as exemplified by two examples from Antinoopolis now in the Louvre (Fig. 12). ${ }^{47}$ Further fragments belonging to the same tunic were located in Rouen a few years ago. One of them, a third medallion depicting another personification identified by lettering as Kairos, the right or opportune moment, fits the iconography for the personification of the autumn (Fig. 13). Here, we have again a deeply symbolic iconography that appears to signify the life cycle and its possible renewal.

Scenes with a singular figure could also be linked through various framing devices, particularly architectural imitations such as arcades, as can be seen in the case of the Meleager and Atalante wall-hanging in the Abegg-Stiftung (Fig. 1). Both protagonists are in this case clad in very elaborate garments bearing small medallions, and Atalante carries a diadem, emphasizing luxury and regal status. They stand in an arcade that is crowned by a triangular pediment with a bird seemingly clasping the hind legs of another animal. Hermes also appears above the capital separating the two main characters. While the two protagonists in that particular case do not interact, they are linked by means of composition in a way that is very similar to what can be observed on relief sculpture, and Asiatic and Attic sarcophagi in particular, where the arcade commonly was used to frame individual figures that often take on a certain statuesque quality. ${ }^{48}$ The very elaborate garments and the luxurious style of the diadem in this case may allude to the figures having a secondary function as participants in a kind of mythological role-play that may have had a particular significance intentional in the funerary context and can be compared with how portraits were applied to mythological figures on Roman sarcophagi. ${ }^{49}$ With its architectural frame,

47 Louvre, inv. no. X 4187, see Bourguet (cf. fn. 18), 75, cat. no. B 25, $5^{\text {th }}$ century; M.-H. Rutschowscaya, Coptic Fabrics (Paris 1990), 119; M. Durand "Inscribed Fabrics from Egypt. A Study in Greek and Coptic Textile Epigraphy”, Journal of Coptic Studies 11 (2009), 157-180, esp. 165-166.

48 On the statuesque, see P. Stewart, Statues in Roman Society. Representation and Response (Oxford 2003), 92-111.

49 For the relationship between this depiction and the issue of self-representation, see also S. Schrenk, “(Wall-)Hangings Depicted in Late Antique Works of Art?”, in: Clothing the House. Furnishing Textiles of the $1^{\text {st }}$ Millennium AD from Egypt and Neighbouring Countries. Proceedings of the $5^{\text {th }}$ Conference of the Research Group ‘Textiles from the Nile Valley’ Antwerp 6-7 October 2007, edited 
the entire composition in fact takes on the appearance of a tomb, complete with pediment. Hermes, seen between the two protagonists, may also have the function as Psychopompos in this context. The floral motifs and birds add to the atmosphere of eternal peace and abundance.

Other framing devices could be used to highlight particular aspects of a mythological narrative or to juxtapose different iconographies. A $6^{\text {th }}$-century tabula is testimony to a particularly local blend of a Nilotic scene, showing putti in small boats and a rich variety of plants and fish, used here to frame a central scene with a depiction of the bathing Aphrodite (Fig. 14). ${ }^{50}$ Such Nilotic scenes were common in Egypt and testify to a tradition of appropriating myth and situating it within one's own natural and physical environment. The bathing Aphrodite is similarly also depicted in the architectural sculpture that adorned contemporary funerary monuments and wherever her cosmic associations seemed appropriate for provoking thoughts on life and death. In other cases, we observe a combination of both single figures and scenes with interacting figures, sometimes also framed within arcade-like architecture..$^{51}$ In one example that was excavated by Gayet at Antinoopolis during the 1902-03 season, 13 fragments have been reconstructed to make up a tunic that is richly adorned with mythological figures such as centaurs and lapiths, which are depicted in a struggle on the two medallions (Fig. 15). The two collar-like rectangular tabulae of the same tunic show amazons on horseback as part of an amazonomachy as well as a series of dual-figure scenes, including Narcissus looking at his reflection in the mirror to the far right. This scene features the nymph Echo, thus seemingly referencing Ovid's version from the Metamorphoses, and suggesting an interesting link between art and text to which we will return below. Amongst other scenes, we see Hercules chasing the nymph Auge as the second from the right, and Aphrodite and Ares (or Adonis) in the centre. This rich and complex iconography amounts to a veritable 'picture-book' from which mythological stories could be conjured up. It is also clear that many of these figures could easily have been represented on their own and it is, therefore, possible that they may have been taken out of a pattern-book from which models could be pulled and juxtaposed as appropriate or desired by the patron. There does not seem to be an overarching narrative that structures the composition of the tunic's decoration other than an interest in depicting mythological pairs, and we should certainly not always expect strict iconographic coherency or an intended programme to be present. ${ }^{52}$

More generally, narrative scenes with multiple figures within the same frame had the great advantage that they allowed for more flexibility in representing interaction

by A. De Moor and C. Fluck (Tielt 2009), 146-154, esp. 149. On the application of portraits on mythological figures on Roman sarcophagi, see Birk (cf. fn. 37), 94-107.

50 Santrot et al. (cf. fn. 34), 122, cat. no. 85. For another example of Aphrodite's bath on textiles, refer to ibid., 123. For Aphrodite on architectural sculpture, see Thomas (cf. fn. 45), 48-49.

51 Louvre, inv. E 29294, see Santrot et al. (cf. fn. 34), 112-113, no. 77, here dated to the $3^{\text {rd }}$ century. 52 A point also made in relation to Pompeian wall-painting by Mayer (cf. fn. 24), 166-212. 
between the protagonists, even between mortals and immortals. ${ }^{53}$ In one example from Antinoopolis, dating to the $5^{\text {th }}$ century, we see a representation of Dionysos in a tabula in which he is joined by a reveller sitting in a boat (Fig. 16). The motif can be compared to a series of grave stelai from Terenouthis in the Delta in which the deceased is represented as standing or lying on a boat. ${ }^{54}$ This motif is usually interpreted as a representation of the journey to Styx, and coins found in graves, presumably placed there in order for the deceased to be able to pay Charon, have been cited in support. But again we may envision a more local iconography that could also refer to the power of the Nile in providing life and fertility, an aspect emphasized here by the rich floral ornamentation that is reminiscent of Nilotic scenes. Either way, it demonstrates once again a use of mythology that reflects the wearer's aspirations for the afterlife.

Staying for a moment with the world of Dionysos, this is indeed a very popular theme on late antique Egyptian textiles which benefits from further scrutiny. What was at stake in these images? And what is the relationship between art and text, notably in the Dionysiac motifs that we see on textiles and the popularity of Nonnus' epic poem Dionysiaca? Anthony Snodgrass amongst others has explored at length just how difficult it is to prove a precise correlation between an image and a specific text, and of course, there are other versions of Dionysiac stories that the textile artisans could have used as their inspiration. ${ }^{55}$ Are we then talking about parallel worlds of art and text? ${ }^{26}$ The presence of text itself is rare on textiles, and when present serves simply to identify the main protagonists in a particular narrative, as we have seen in a number of cases above. ${ }^{57}$ Yet, dialogue between art and text may of course also take other forms, as was for example argued in the above case of Narcissus and Echo. Intriguingly, Nonnus was himself from Akhmim, thus representing a possible link between these two forms of expression. We also know from evidence, such as a $6^{\text {th }}$-century papyrus that quotes parts of the Dionysiaca from memory that the poem was read and had become quite popular very soon after its publication. ${ }^{58}$ A plethora of recent literature has emphasized the ways in which the work could be read and appreciated by pagans and Christians alike, and pointed to the many inter-textual references that exist between this work and a paraphrase of the Gospel of John, possibly written by Nonnus. ${ }^{59}$

53 Louvre, inv. X 4792, see Bourguet (cf. fn. 18), 74, cat. no. B 24, from Antinoopolis.

54 F. Hooper, Funerary Stelae from Kom Abou Billou (Ann Arbor, MI 1961), 25.

55 A. Snodgrass, Homer and the Artists. Text and Picture in Early Greek Art (Cambridge 1998).

56 Here echoing J. P. Small, The Parallel Worlds of Classical Art and Text (Cambridge 2008).

57 Durand (cf. fn. 47).

58 R. Shorrock, "Nonnus", in: A Companion to Ancient Epic, edited by J. M. Foley (Malden, MA 2005), 383.

59 R. Shorrock, The Myth of Paganism. Nonnus, Dionysus and the World of Late Antiquity (London 2011); Accorinti in this volume. 
Nevertheless, it may well be the case that such visual representations developed on their own independent trajectory. An example may demonstrate that this is very likely to have been the case. We previously saw a representation of Dionysos finding Ariadne on a tunic (Fig. 5) which framed the two protagonists in a similar way to the use of the motif on sarcophagi or in wall-painting. This theme is elaborately described in the $47^{\text {th }}$ book of the Dionysiaca, in which Ariadne, having been deserted by Theseus, longs to fall asleep and is then finally saved by Dionysos. In the case of a $5^{\text {th }}$-century tunic now in the Metropolitan Museum of Art and said to be from Akhmim, we see a variety of Dionysiac motifs, as well as another depiction of Dionysos and Ariadne on a tabula on the shoulder (Fig. 17). Below them are seated two figures seemingly with their hands tied behind their backs. This is rather odd, but may represent a misunderstanding of the standard iconography in which Dionysos and Ariadne are accompanied by putti and revellers. There seems to be no attempt to tie the story to its literary counterpart, not even through the identification of the figures by means of letters.

Yet, in spite of this reservation, the Dionysiaca may hold significance as an eschatological text within the funerary context and thus provide some further context for understanding the meaning of the Dionysiac motifs that were chosen for the adornment of textiles. The text describes Dionysos' life as a series of struggles which he must overcome in order to be given admission to heaven and represents as such a quest for salvation, which would have appealed to both pagans and Christians. Within the text, there are furthermore embedded stories of death and subsequent resurrection, such as the case of Tylos in the $25^{\text {th }}$ book, a story that frequently has been compared with the Biblical Lazarus which Nonnus also tells in his Paraphrase of the Gospel of John. ${ }^{60}$ This Lydian hero is killed by a serpent but then resurrected to life by his sister Moira who cleverly applied an antidote, known as the

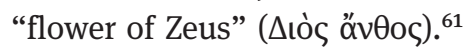

The case of Ariadne is also illuminating in this context. One of the most significant aspects of Ariadne's appearance in the Dionysiaca is that she is killed off not once, but twice; first, in the $25^{\text {th }}$ book, Perseus kills her with a spear (25.98-112), and then again, in the $47^{\text {th }}$ book, Ariadne is petrified when Perseus exposes her to the deadly face of Medusa, much to the anger of Dionysos who loses his bride, but in the end, she is given a home in the heavens (47.664-712). This metaphorical reading of the text as one of trial but also ultimate reward may again have been suitable for pagans and Christians alike and goes some way in explaining why Dionysiac motifs (and not least representations of Ariadne in particular) were so frequently favoured on late antique Egyptian textiles intended for the funerary sphere. ${ }^{62}$ Ariadne's

60 Shorrock (cf. fn. 59), 97-98.

61 Non., Dio. 25.528, 25.539.

62 V. F. Lenzen, The Triumph of Dionysos on Textiles of Late Antique Egypt (Berkeley, CA 1960) explores this theme from the viewpoint of representation, but does not dwell on its eschatological significance. 
long monologue in book 47 where she addresses Sleep and asks "to send me another delectable dream ... so that that I may know the sweet bed of love in a deceptive dream" (47.345-347) may also be read along eschatological lines as a metaphor of death and the afterlife. ${ }^{63}$

This leads us to the much discussed question of the Christianizing fashion in which pagan deities are described in the Dionysiaca, a phenomenon which has been explored by Glen Bowersock amongst others. ${ }^{64}$ Can this phenomenon be identified among the textiles as well? In relation to this question, much has been made of a cruciform flower that is found on the so-called Shawl of Sabina, excavated by Gayet at Antinoopolis in the 1902-1903 season and which is worthy of further exploration in the present context (Figs. 18-19). ${ }^{65}$ This particular piece of textile gives us a good sense of the extraordinary use of colour on the textiles. The shawl, which is now in the Louvre with further fragments in other collections, is decorated with two tabulae that represent Artemis, and Apollo and the nymph Daphne respectively. A central orbiculus has been interpreted as representing Bellerophon, Pegasus, and the Chimaera. It was previously dated to the $6^{\text {th }}$ century, but new radiocarbon results point to an earlier date around $340-440 .{ }^{66}$ Because of the high quality of this particular textile and its original iconography, it has been suggested that it functioned as a wall hanging or even a type of table cloth (and then was re-used in the funerary context) - but that does not necessarily detract from its funerary significance.

The shawl was found in a tomb that belonged to a woman named Sabina, hence its modern name. She was buried with a Gnostic stone, an ivory fish, a glass vase with a cross and the letters alpha and omega, strongly indicating that it belonged to a Christian occupant. ${ }^{67}$ So, it seems that we here have a Christian funerary context in which textiles with representations of pagan mythology featured very prominently.

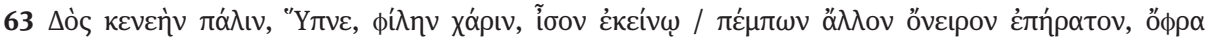

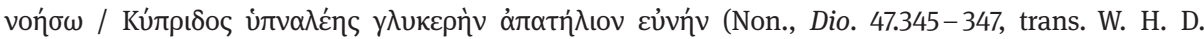
Rouse). For an exploration of sleep as a metaphor of death and a form of epiphany, refer to, most recently, V. Platt, Facing the Gods. Epiphany and Representation in Graeco-Roman Art, Literature and Religion (Cambridge 2011), 335-393. For Ariadne on Roman sarcophagi, see Birk (cf. fn. 37), index, 'Ariadne'.

64 G. Bowersock, "Dionysus as an Epic Hero", in: Studies in the Dionysiaca of Nonnus, edited by N. Hopkinson (Cambridge 1994), 156-166; and see Shorrock (cf. fn. 59).

65 Musée du Louvre, inv. E 29302, excavated by Gayet at Antinoopolis in 1902-1903 and went on display immediately after in the Musée Guimet in Paris from which it was later transferred to the Louvre. H: $1.10 \mathrm{~m}$. W: $1.40 \mathrm{~m}$. Further fragments belonging to the same textile are also in Lyon (Musée des Beaux-Arts and Musée Historique des Tissus). The key publication is now M.-H. Rutschowscaya, La châle de Sabine (Paris 2012). See also idem., "La châle de Sabine", in: Études coptex VI. Huitième journée d'études. Colmar 29-31 mai 1997 (Paris 1997), 21-28; Santrot et al. (cf. fn. 34), 108-111, no. 76. The iconography of Apollo and Daphne is also discussed in A. Stauffer, Spätantike und koptische Wirkereien. Untersuchungen zur ikonographischen Tradition in spätantiken und frühmittelalterlichen Textilwerkstätten (Bern 1992), 145-148.

66 Rutschowscaya 2012 (cf. fn. 65), 115-117.

67 E. Guimet, Les portraits d'Antinoé (Paris 1912), 17. 
In one of the tabulae, Daphne holds a cruciform flower in her hand. The flower is centrally placed within the frame of the figural panel, suggesting that it may be an important part of the iconography. It has been interpreted as a sign of the Christianization of the scene and caused quite a sensation upon its discovery ${ }^{68}$ However, there are many reasons to be careful with such interpretations, as in other contexts, artists had no problems representing full-blown mythological narratives without any need to Christianize them through the addition of crosses or any other form of Christian iconography. The cross (if that is what it really is) is furthermore an isolated Christianizing element in the present example. We may therefore instead ask whether a particular aspect of the story of Apollo and Daphne was emphasized by the addition of the flower which clearly stands out through the use of the rich red colour.

First, we need to address the overall composition of the piece. The textile applies a strongly heroizing iconography which would befit a funerary context and which can be compared with the use of mythological motifs on Roman sarcophagi. Artemis is shown as a huntress but furthermore represented in the guise of Virtus, and indeed a dead lion lies at her feet; on sarcophagi, Virtus is frequently shown as accompanying a lion hunter or huntress. ${ }^{69}$ The story of Bellerophon is a further pointer to the heroic function of the iconography. ${ }^{70}$ This scene plays off the composition of the Artemis panel by depicting the slain Chimaera, lying on the ground. Bellerophon continued to be popular in Constantinople, where he is famously represented on the $10^{\text {th }}$. century Veroli casket, now in the Victoria \& Albert Museum. Circling around this central orbiculus, playful putti are represented as taking part in a variety of leisurely activities, including playing music, being crowned by wreaths, and riding a centaur. Among the different floral ornaments, we see below the Artemis panel, a trefoil which looks rather suspiciously similar to our red cruciform flower that Daphne holds in her hand. The main scenes are framed by Nilotic scenes on the clavi.

Zooming in now on the representation of Apollo and Daphne, the artisan has here tackled the difficult task of visualizing metamorphosis in action as Daphne is shown half-way into her transformation into a laurel tree. ${ }^{71}$ Indeed, the tree appears to be swallowing her, and her feet are already covered. This finds a close parallel in another Egyptian artefact, the ivory which is now in Ravenna. ${ }^{72}$ In contrast to the textile, Apollo is shown here with a lyre (thus emphasizing a less bellicose aspect of his identity), and although Daphne gestures towards him, she does not hold anything in her hand. On another textile fragment, now on the Zurich art market, we see a statu-

68 Guimet (cf. fn. 67), 18, and repeated in Santrot et al. (cf. fn. 34), 108.

69 For examples, see B. Andreae, Die antiken Sarkophagreliefs I. Die Sarkophage mit Darstellungen aus dem Menschenleben. 2. Die römischen Jagdsarkophage (Berlin 1980). See also Birk (cf. fn. 37), 107-114, 137-138.

70 Bellerophon in the Iliad: vi.155-203. For an example of the use of the myth of Bellorophon on a Roman sarcophagus, see Zanker and Ewald (cf. fn. 33), 301-304.

71 See also S. Woodford, Images of Myths in Classical Antiquity (Cambridge 2003), 165-166.

72 LIMC, Daphne 35. 
esque Apollo - and perhaps two representations of Daphne in different stages of the narrative; one of her metamorphosis and one of her running from Apollo, although this figure has also been interpreted as representing another nymph. ${ }^{73}$ In this example, we see how standard figures could be placed together to make up a story, even when only little effort has been made to show interaction between them. On a $7^{\text {th }}$ - to $9^{\text {th }}$-century tunic in the Abegg-Stiftung, a similar iconography may be recognized, but the figures are now depicted as dressed rather than nude. ${ }^{74}$ Furthermore, Daphne is depicted in Egyptian architectural sculpture, such as in an example from Herakleopolis Magna where the laurel tree looks rather less convincing than in the case of the Shawl of Sabina and where she is depicted on her own. ${ }^{75}$

This practice of isolating and juxtaposing single figures for different uses may explain why Apollo in the piece under discussion looks as if he is taken from a version of him killing the Niobids since he is shown reaching for his quiver in the standard iconography of a hunter - imagery that is also used in the case of the Atalante in the Abegg-Stiftung. This posture adds a certain irony to the story, in that in Ovid's Metamorphoses, Apollo lampoons Eros for handling big weapons and thus provokes his shooting by the arrow of love. But this posture has certainly also been chosen to make an iconographic link to the representation of Artemis, who is also portrayed on the textile with a bow. This juxtaposition comes through in the choice of colour as well; Apollo's bow is white, that of Artemis is, by contrast, black. Apollo's posture furthermore adds to the sense of (erotic) tension that is implicit in the scene; she reaches out to him, and he reaches to his quiver.

In comparison with these and other iconographic comparanda, the flower in Daphne's hand appears to be idiosyncratic, as in no other representations of the scene is she shown holding a similar object. Nor does the gesture resonate with any textual version of the story that I know of. This hints at an individual meaning which is difficult to reconstruct. Daphne may be appealing to Apollo, her father, or even evoking Zeus, as in Parthenius' version of the story, but we cannot be certain. ${ }^{76}$ In Parthenius' version, we are also told that Artemis taught Daphne how to shoot straight, thus creating a link between this panel and that showing Artemis and also a possible correlation between art and a particular text. The overall message of this piece of textile may then be to express various qualities of maidenhood that were appropriate for an unmarried girl. Furthermore, another fragment of the shawl that is now in Lyon apparently focuses on an aspect of ideal beauty. This piece shows an orbiculus, supported by two putti, that depicts Aphrodite's bath. ${ }^{77}$

73 LIMC, Daphne 40a. On the story of Daphne and its interpretation, see K. Dowden, Death and the Maiden. Girls’ Initiation Rites in Greek Mythology (London 1989), 174-179.

74 Stauffer (cf. fn. 65), 145-146; Schrenk (cf. fn. 3), 169-171, cat. no. 57.

75 LIMC, Daphne 4. Cairo, Coptic Museum 7061, dated to the $5^{\text {th }}$ or $6^{\text {th }}$ century.

76 Parthenius, Sufferings in Love, XV.

77 Rutschowscaya (cf. fn. 47), fig. 7. 
In answer to the question of whether the cruciform flower constitutes evidence for a Christian appropriation of the myth of Apollo and Daphne by means of the addition of a cross, I think that we should be very hesitant, in spite of the seemingly Christian finds that also were in the grave. In light of the idiosyncratic iconography that has been chosen for this particular textile, rather different meanings related to the wearer's identity rather than her religious affiliation may very well have been intended. Overall, the unusual iconography of the Shawl of Sabina may be explained by reference to license on behalf of the artist or the patron.

The continuity that these mythological images on Egyptian textiles attest to seems to be a subtle one which places the viewer at centre stage, allowing him or her to read different meanings into individual motifs, similar to how the Dionysiaca may have been read by both Christians and pagans, in spite of what appears, at least on the surface, to be a full-fledged pagan mythological narrative. Evidence, such as the newly discovered late antique house at Trimithis (Amheida) in the Dakhla Oasia, whose walls were decorated with mythological scenes and a rhetorical teacher's dipinto, certainly suggests that Greek literary tradition and education was alive and well into the fourth century, even beyond Alexandria and the Nile Valley. ${ }^{78}$ This means that we should not see the textiles as increasingly devoid of meaning, but rather as bearers of an iconographic tradition that helped to make sense of everyday life and the ways in which personhood was forged and represented in different media. The textile evidence suggests that this tradition was vital at least into the $6^{\text {th }}$ century. Do the mythological motifs then constitute Documents of Dying Paganism, to quote the title of one influential study? ${ }^{79}$ No, rather they attest to the complexity of religious change in Egypt. Recent work by Jitse Dijkstra on Philae has indeed shown just how complex the reality of pagan-Christian interaction was during this period. ${ }^{80}$ The mythological scenes on textiles are furthermore testament to a very powerful tradition in which conceptions of eschatology and other crucial aspects of life could be expressed through mythology which had already been appropriated within the Egyptian cultural canon. In this context, mythology functions as a habitus rather than as a religious system. ${ }^{81}$ By dressing themselves in myth, in life and for the afterlife, late antique Egyptians confronted the same sort of issues of representation and identity that are observed on contemporary funerary sculpture and in earlier Roman sarcophagi, thus linking their cultural and religious aspirations to the wider world of the Mediterranean.

78 R. Cribiore, P. Davoli, and S. Ratzan, “A Teacher's Dipinto from Trimithis (Dakhleh Oasis)”, JRA 21 (2008), 170 -191. See also A. Benaissa, “Greek Language, Education, and Literary Culture”, in: Oxford Handbook of Roman Egypt, edited by C. Riggs (Oxford 2012), 526-542.

79 P. Friedländer, Documents of Dying Paganism. Textiles of Late Antiquity in Washington, New York, and Leningrad (Berkeley 1945).

80 J. Dijkstra, Philae and the End of Ancient Egyptian Religion. A Regional Study of Religious Transformation (298-642 CE) (Leuven 2008).

81 Compare K. Bowes, “Christian Images in the Home”, AnTard 19 (2011), 171-190. 


\section{Epilogue}

When addressing the gradual disappearance of mythological motifs on Egyptian textiles it is often noted that from the $6^{\text {th }}$ century onwards, we witness an interesting development that most frequently has been characterized as a descent into form, stylized representations or even caricature, seemingly rendering figures and motifs increasingly devoid of meaning. Examples of this phenomenon can be found on a $7^{\text {th }}$ century wool tunic now in the Brooklyn Museum, the representation of Dionysos descends into heavily stylized ornament which is barely legible but still potentially meaningful (Fig. 20). ${ }^{82}$ Nereids and other mythological motifs lived on, although in a sometimes rather curious and increasingly abstract form. All of this makes it very difficult to define the limits of the use of mythology on Egyptian textiles, which it must be noted, co-existed with Christian motifs. This is a rather striking contrast to developments in other parts of the Mediterranean. For example, in a study of North African lamps, John Lund has shown that mythological motifs in this medium experienced a rapid decline in the first part of the $5^{\text {th }}$ century and were then entirely replaced by Christian ones. ${ }^{83}$ Arja Karivieri has similarly shown that this process occurred about 50 years later in the case of Athenian lamps, although in this instance the mythological motifs re-appeared in the $6^{\text {th }}$ century. ${ }^{84}$ This is testimony to the many regional variations and trajectories in the process of Christianization. Given the problems of chronology outlined earlier, our Egyptian textiles cannot be exposed to the same kinds of statistical analyses as lamps, but the enormous quantities of material still allow us to confront a question of considerable importance, namely the factors that were responsible for the prevalence of such motifs in the Egyptian context.

82 Brooklyn Museum, acc. no. 41.523, see Thompson (cf. fn. 1), 84-87, no. 37. Very similar piece in the Louvre: Bourguet (cf. fn. 18), 542, cat. no. H 115 (giving $11^{\text {th }}$ c. date).

83 J. Lund, "Motifs in Context: Christian Lamps", in: Late Antiquity. Art in Context, edited by J. Fleischer, J. Lund and M. Nielsen (Copenhagen 2001), 199-214.

84 A. Karivieri, "Mythological Subjects on Late Roman Lamps and the Persistence of Classical Tradition”, in: Late Antiquity. Art in Context, edited by J. Fleischer, J. Lund and M. Nielsen (Copenhagen 2001), 179-198. 


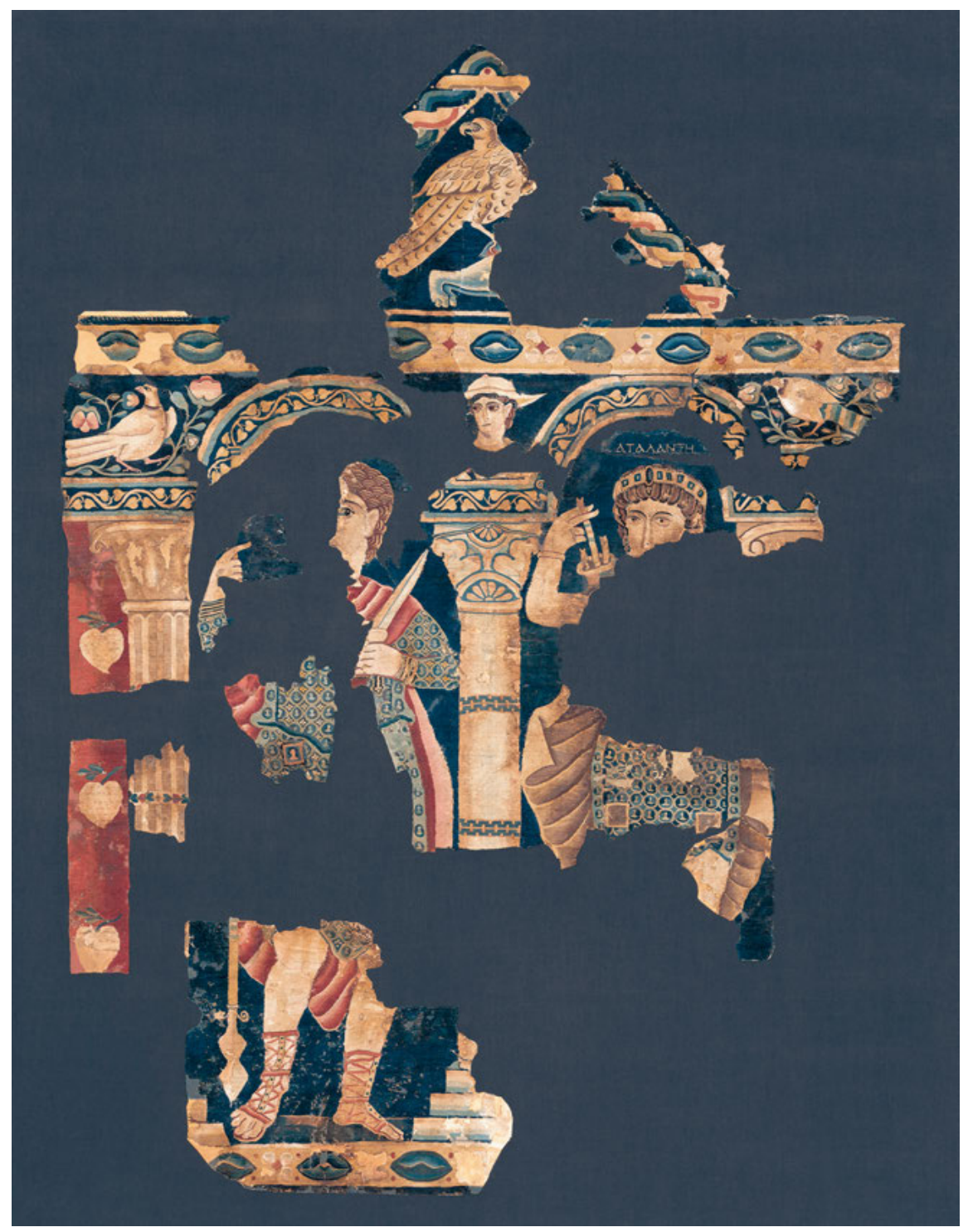

Fig. 1: Meleager and Atalante, Abegg-Stiftung, Riggisberg, inv. no. 1100 (৫ Abegg-Stiftung, CH-3132 Riggisberg, 2003, photo: Christoph von Viràg). 


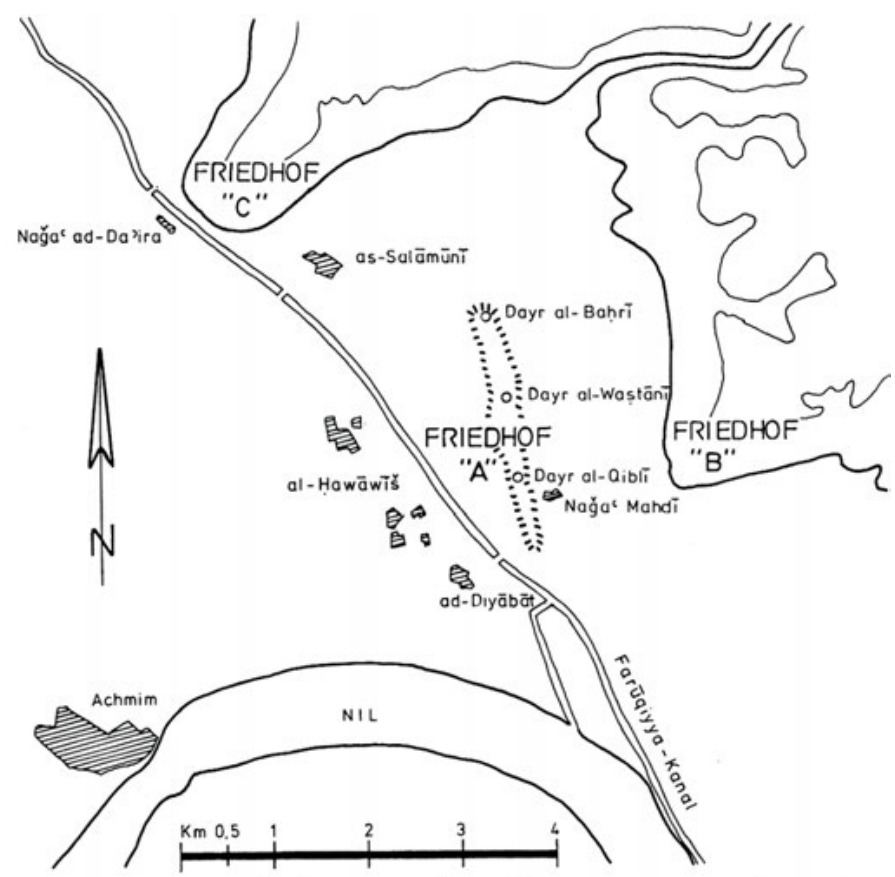

Abb. 14. Die Friedhofsbezirke der Achmimer Wüstennekropole $\mathrm{A}=$ al-Hawāwīš $-\mathrm{B}=(\mathrm{Bayt})$ al-Madīna ( $P M$ : el-Hawâwîsh $)$ $-\mathrm{C}=$ as-Salāmūn̄̄

Fig. 2: Map of cemeteries in the vicinity of Akhmim/Panopolis (from Kuhlmann [cf. fn. 5], 53, by permission of the author).

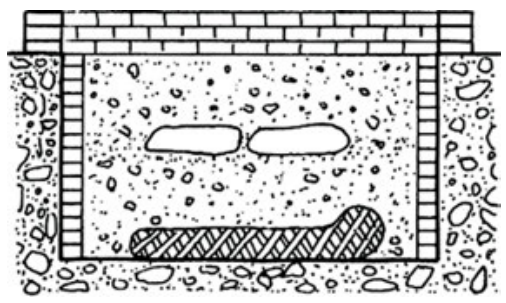

Fig. 3: Drawing of a Christian tomb from cemetery A (see Fig. 2) at Akhmim/Panopolis (from Kuhlmann [cf. fn. 5], 62 , by permission of the author). 


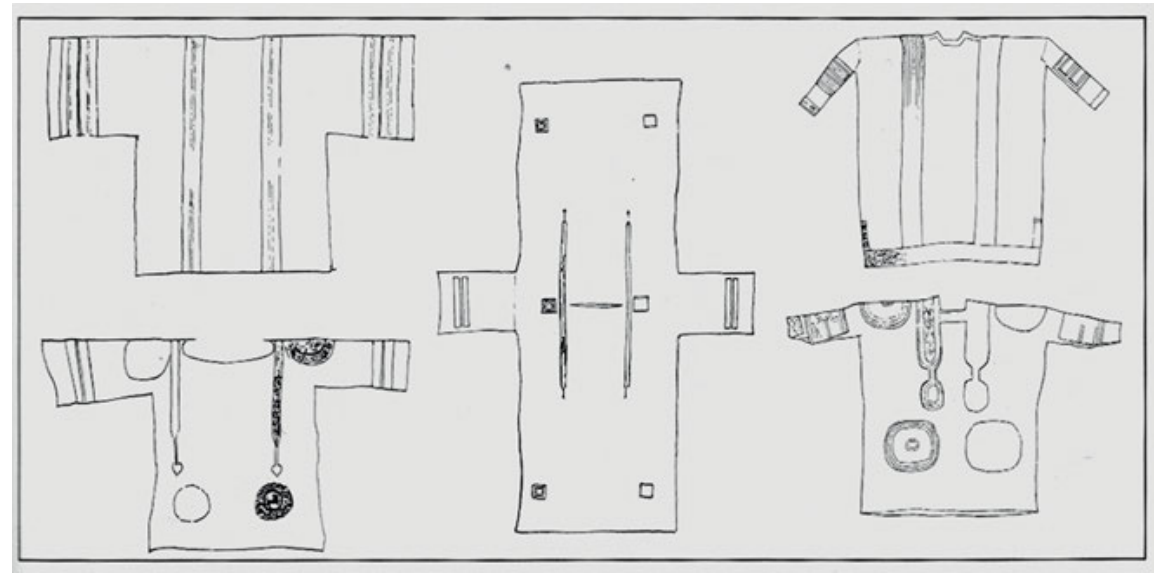

Fig. 4: Drawings of tunics in the Victoria \& Albert Museum, London (from A. Badawy, Coptic Art and Archaeology [Cambridge, MA 1978], 285, fig. 4.60, by permission of the publisher).

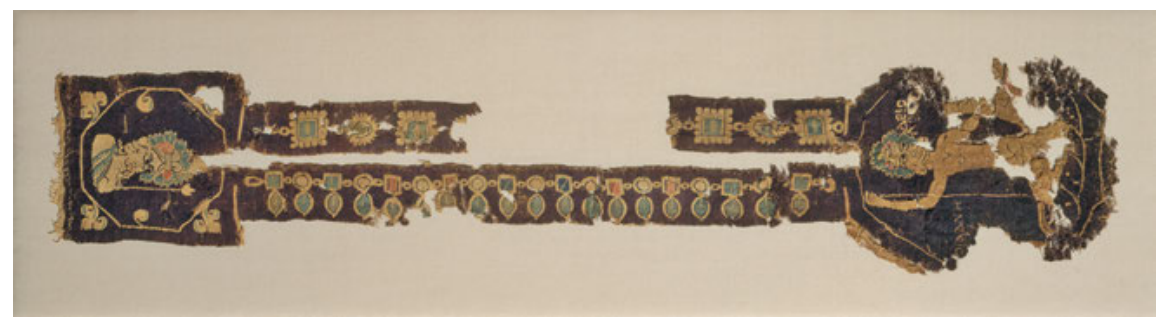

Fig. 5: Neck ornament from tunic, found in Egypt, probably $4^{\text {th }}$ century, Boston Museum of Fine Arts, Charles Potter Kling Fund 46.402 (photo @ Museum of Fine Arts, Boston).

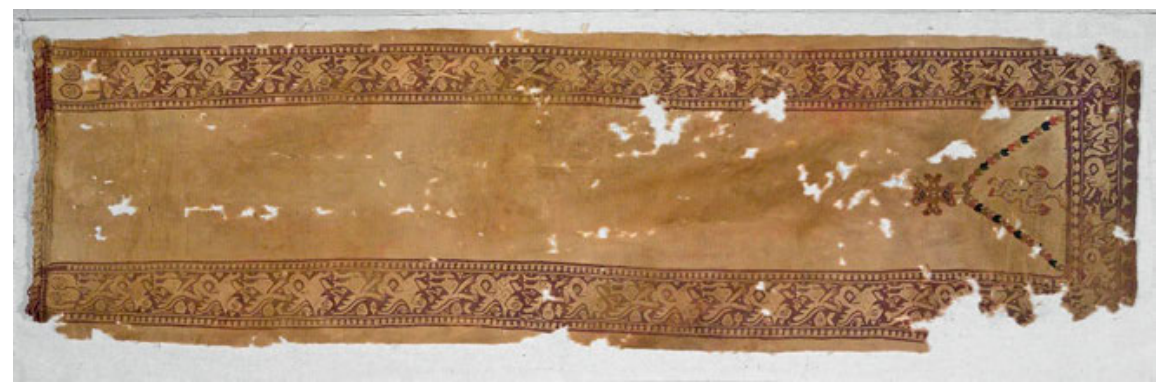

Fig. 6: Yellow tunic - front with marine motifs, $6^{\text {th }}$ century, wool, $33 \times 113 \mathrm{~cm}$, Brooklyn Museum, Charles Edwin Wilbour Fund, acc. no. 38.753 (Brooklyn Museum photograph 2005). 


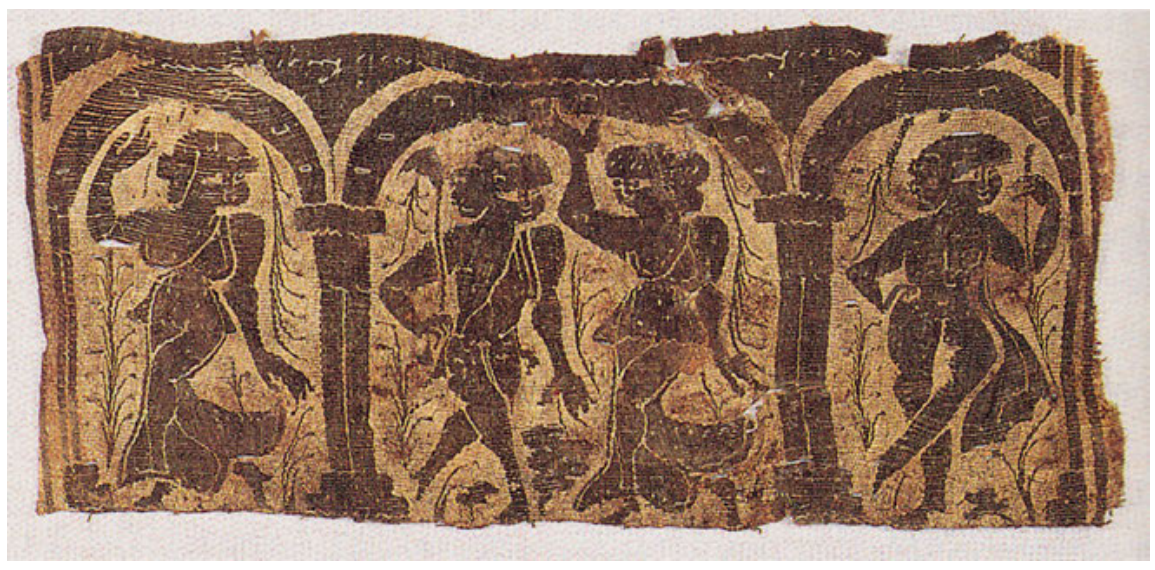

Fig. 7: Tunic panel with dancing figures, $4^{\text {th }}-6^{\text {th }}$ century, Röhsska Museet, Gothenburg, RKM 8-67 (from Erikson [cf. fn. 5], 106, reproduced by permission of the museum).
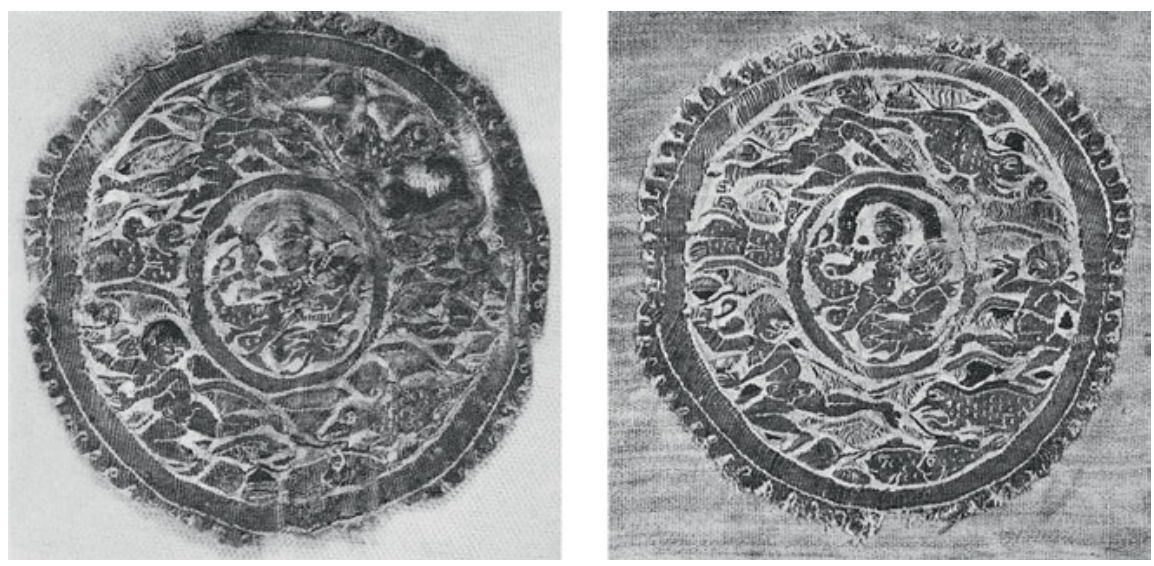

Fig. 8a-b: Pair of $6^{\text {th }}$-century medallions, now in the Louvre, inv. X 4339 \& X 4311 (from Bourguet [cf. fn. 18], 98). 


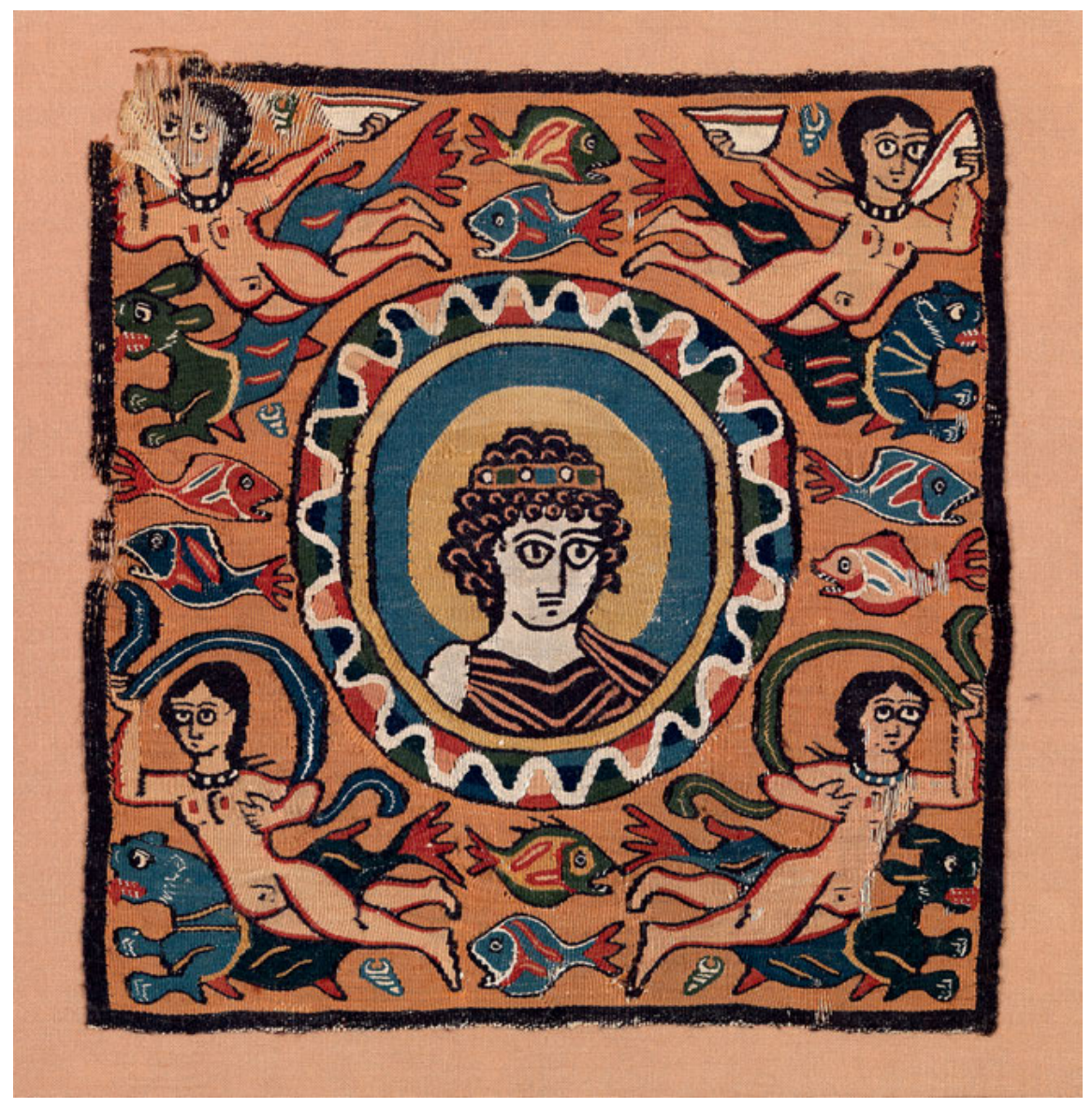

Fig. 9: Medallion portrait, now in the Louvre (๔ Musée du Louvre/Georges Poncet). 


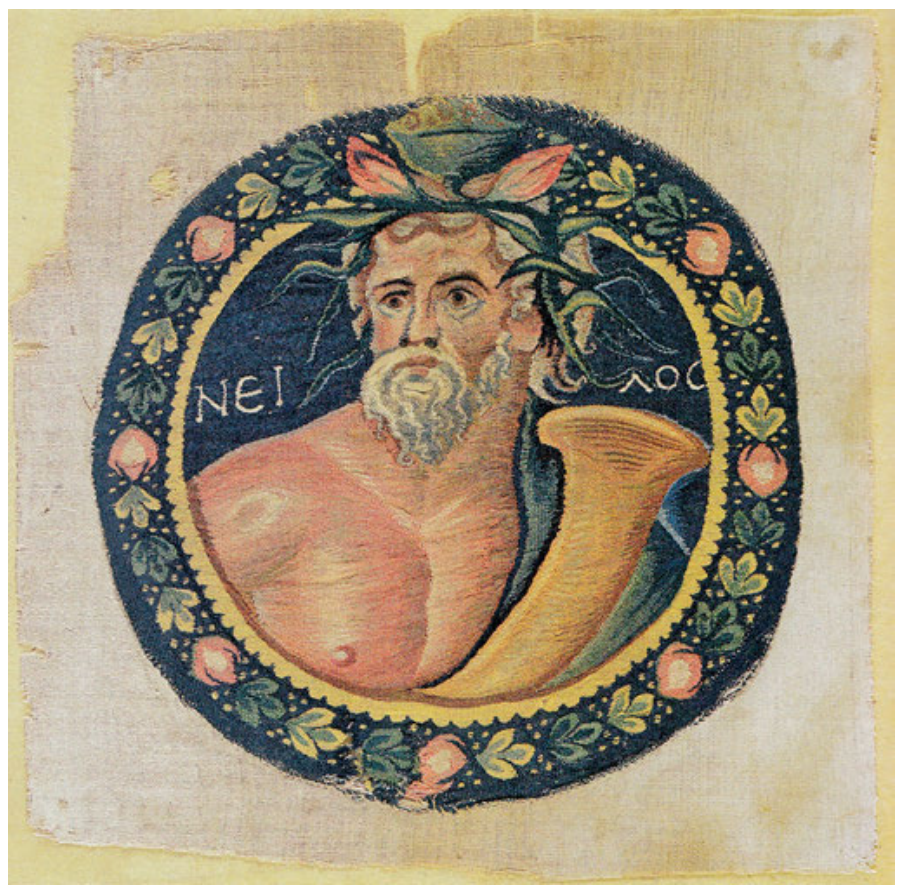

Fig. 10: Personification of the Nile, now in the Pushkin Museum, Moscow (from von Falck and Lichtwark [cf. fn. 35], 308).

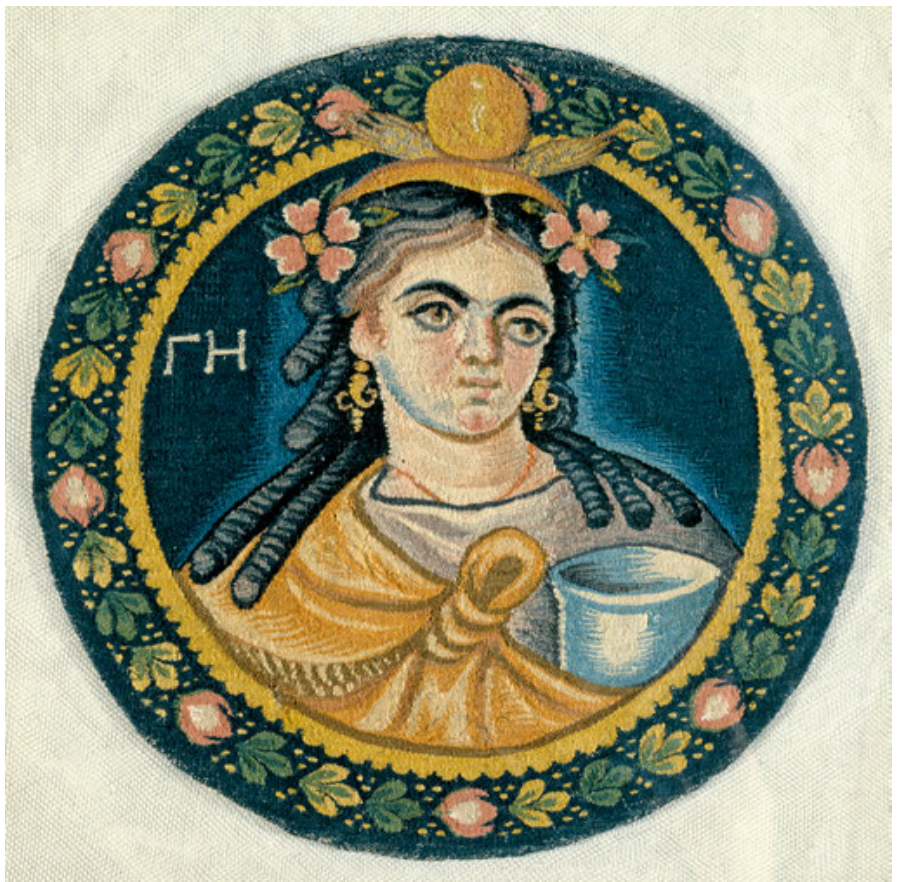

Fig. 11: Personification of $\mathrm{Ge}$, now in The State Hermitage Museum, St. Petersburg (photo (c) The State Hermitage Museum, photo by Svetlana Suetova). 


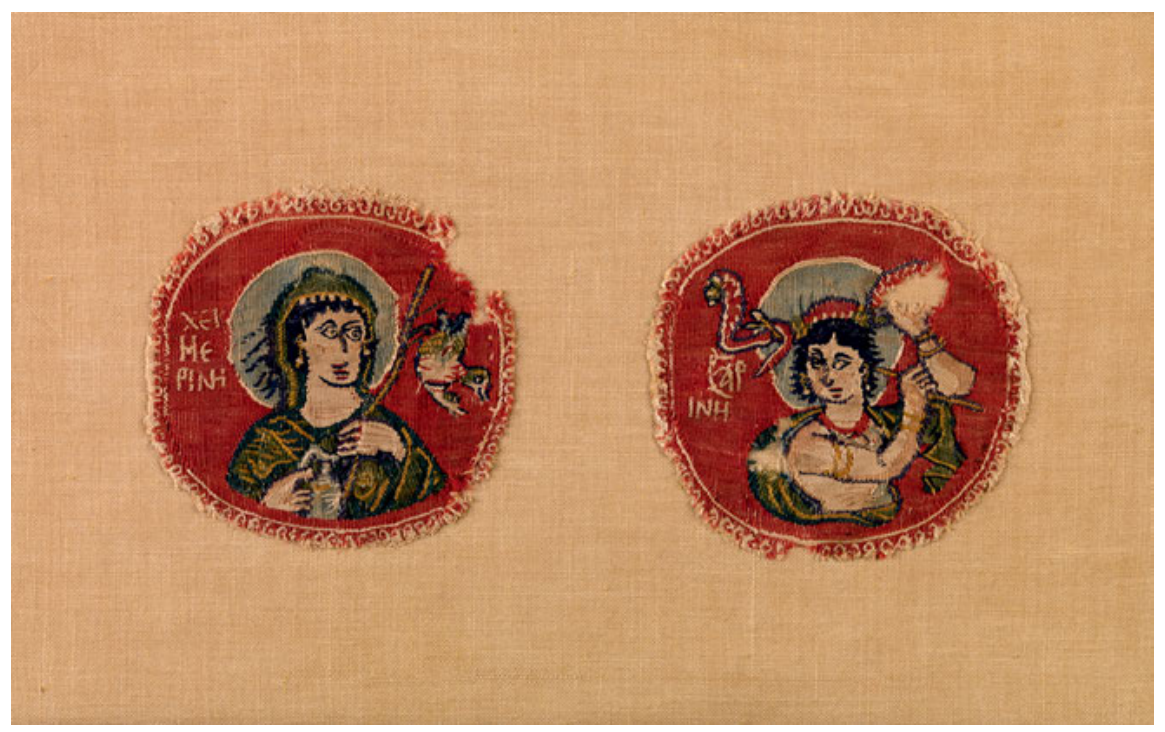

Fig. 12: Seasonal personifications on a tunic, now in the Louvre (from Rutschowscaya [cf. fn. 47], 119).

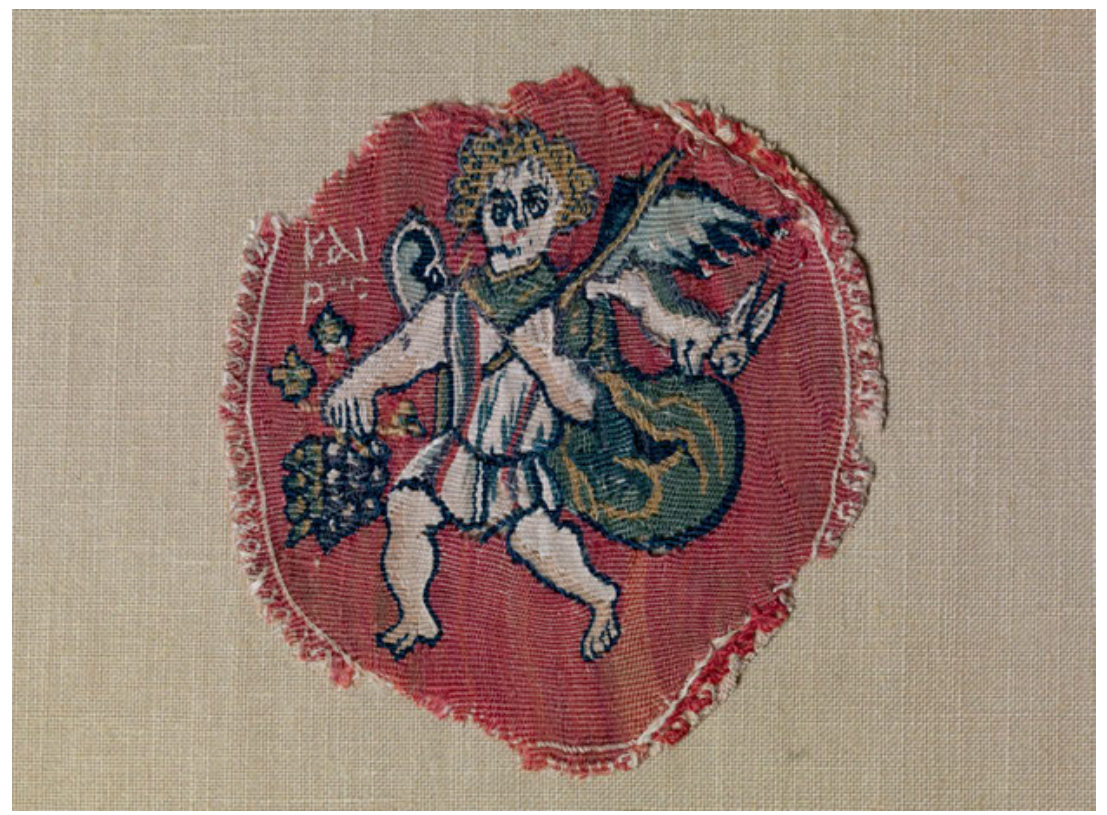

Fig. 13: Personification of Kairos, Musée departmental des Antiquités, Rouen, inv. 2002.0.14 (Photograph ( cg76 - Musée departmental des Antiquités - Rouen, cliché Yohann Deslandes). 


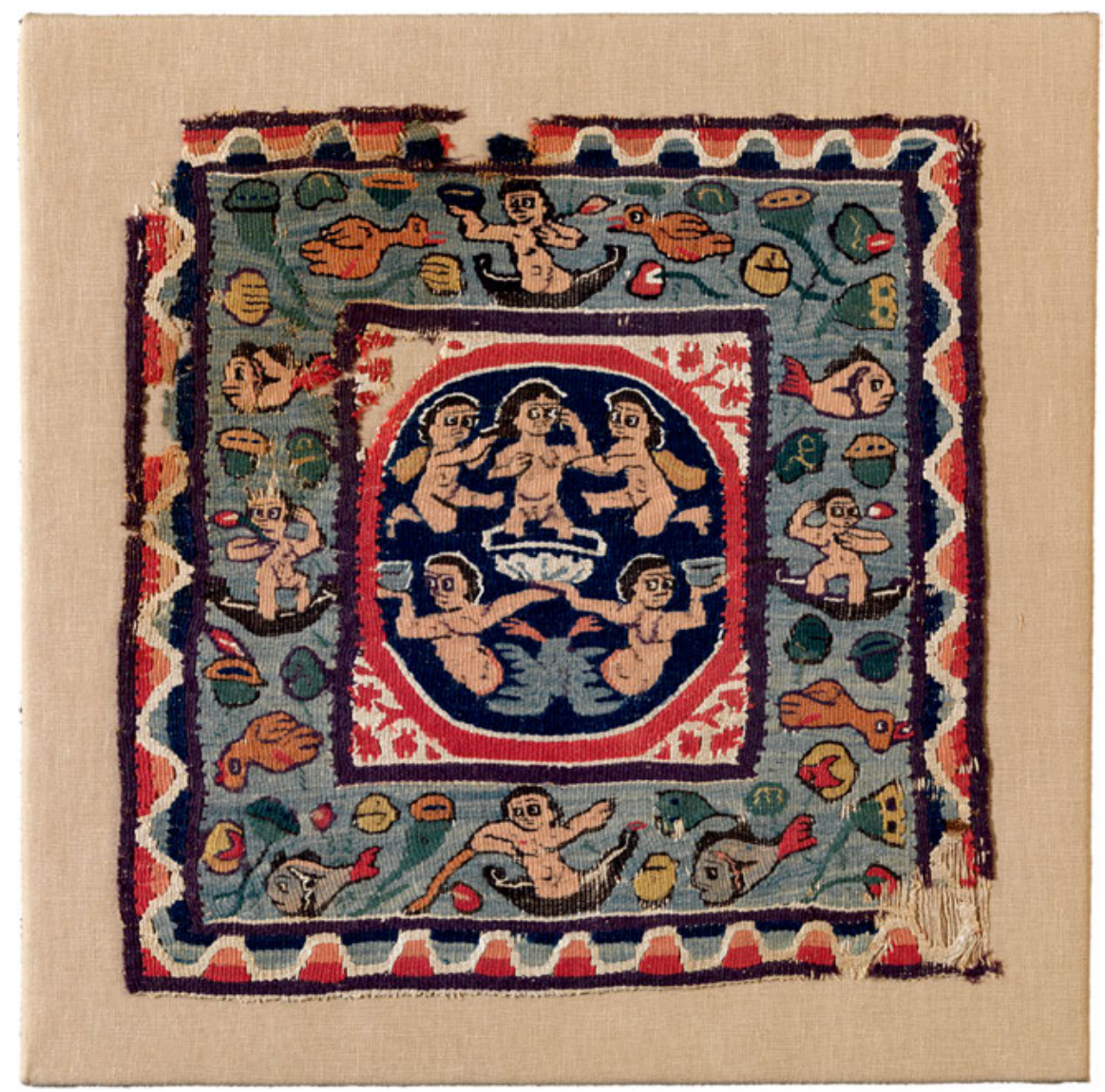

Fig. 14: Tabula with Nilotic scenes and the bathing Aphrodite, Louvre, inv. X 4151 (๑ Musée du Louvre/Georges Poncet). 


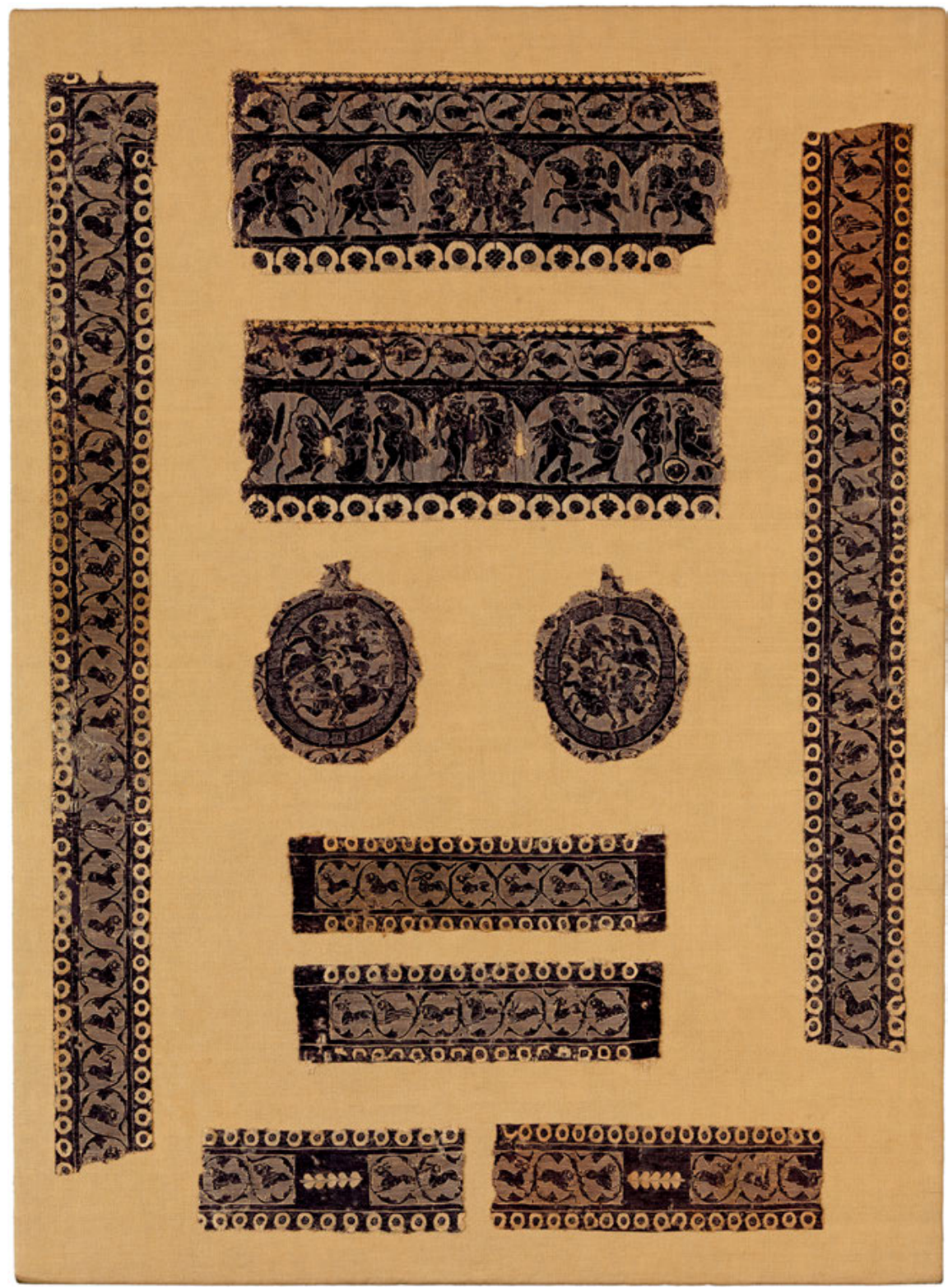

Fig. 15: Tunic in the Louvre, inv. E 29294 (৫ Musée du Louvre/Georges Poncet). 


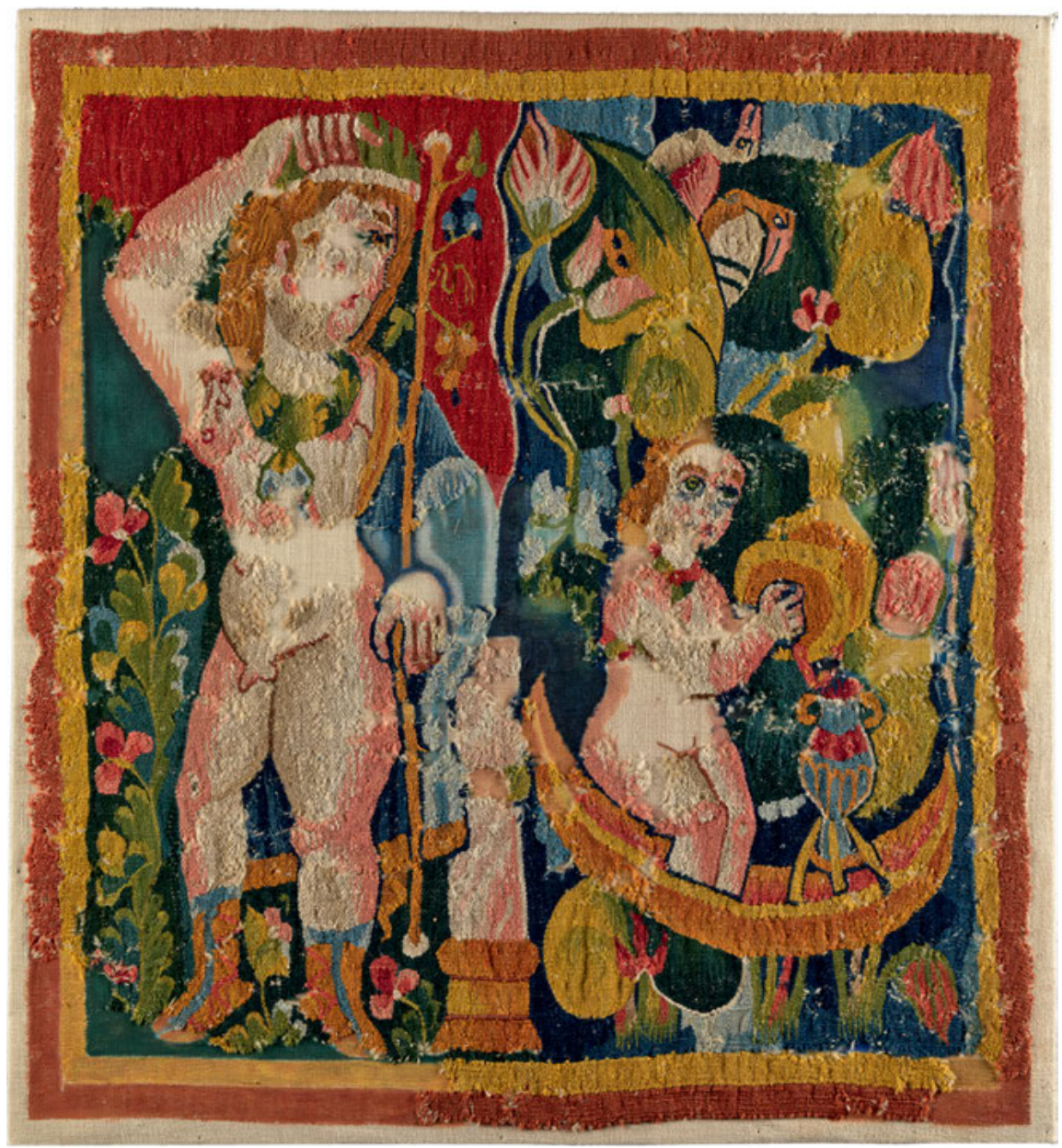

Fig. 16: Tabula showing Dionysos and reveller in a boat, now in the Louvre, inv. X 4792 (from Bourguet [cf. fn. 18], 25). 


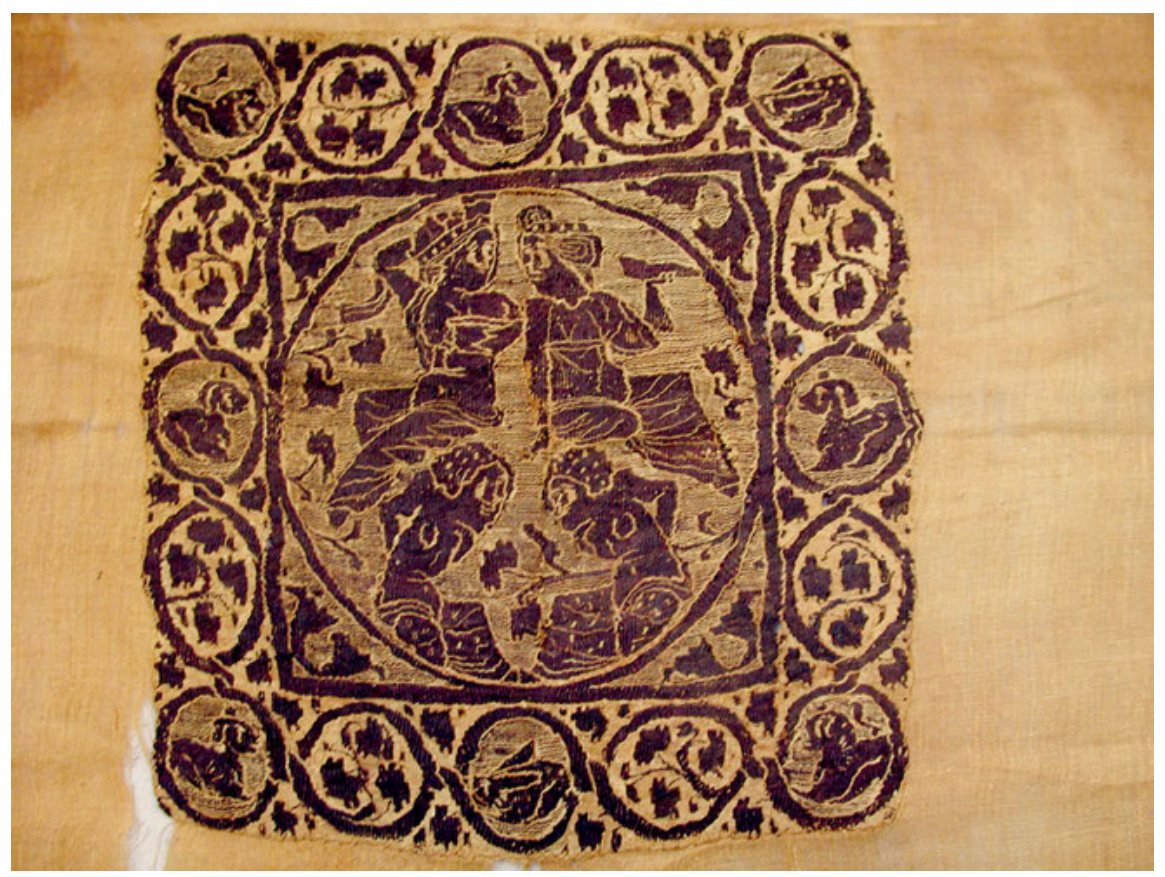

Fig. 17: Ornament from a tunic showing Dionysos and Ariadne, The Metropolitan Museum of Art, New York, Gift of Edward S. Harkness, 1926 (inv. 26.9.8) (Image (c) The Metropolitan Museum of Art). 


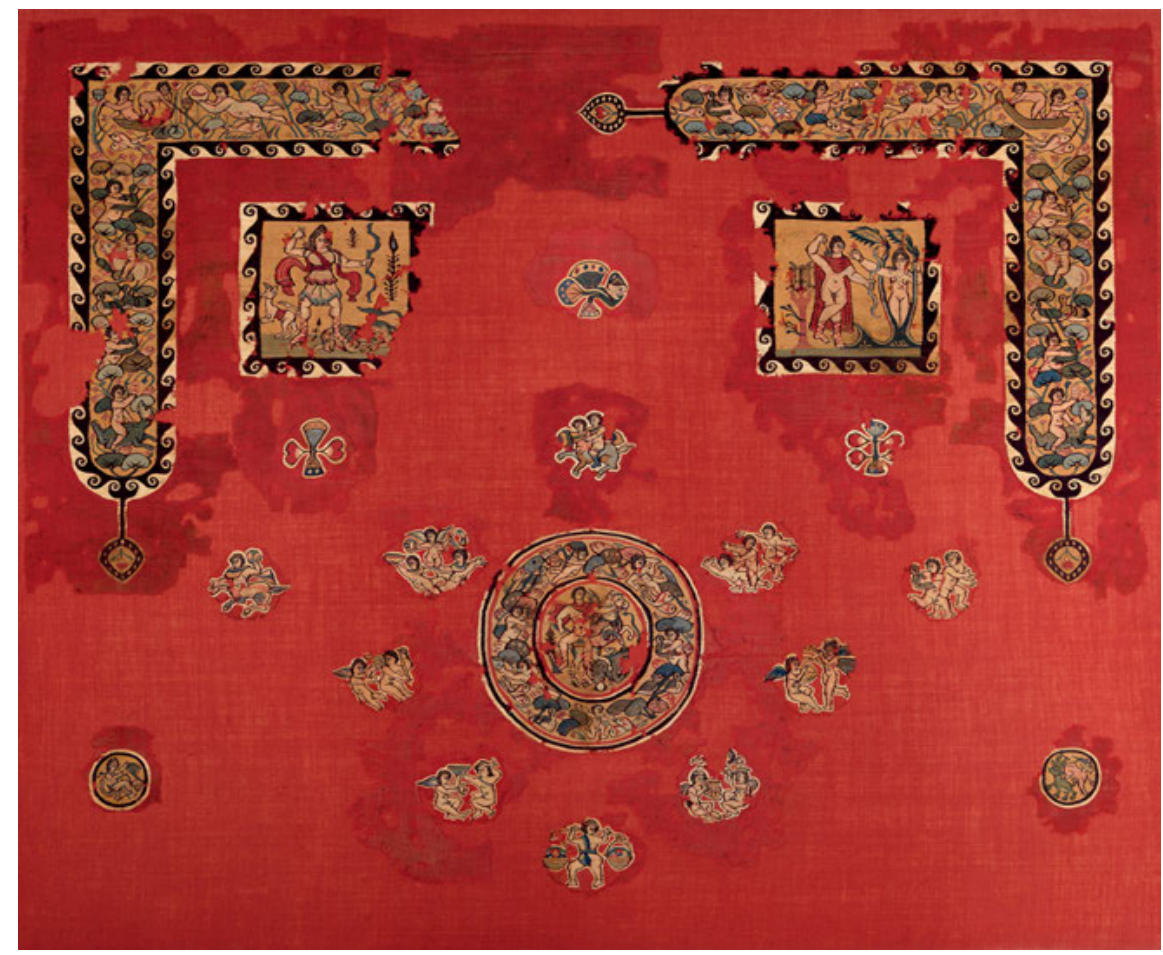

Fig. 18: The so-called "Shawl of Sabina", now in the Louvre (๑ Musée du Louvre/Georges Poncet). 

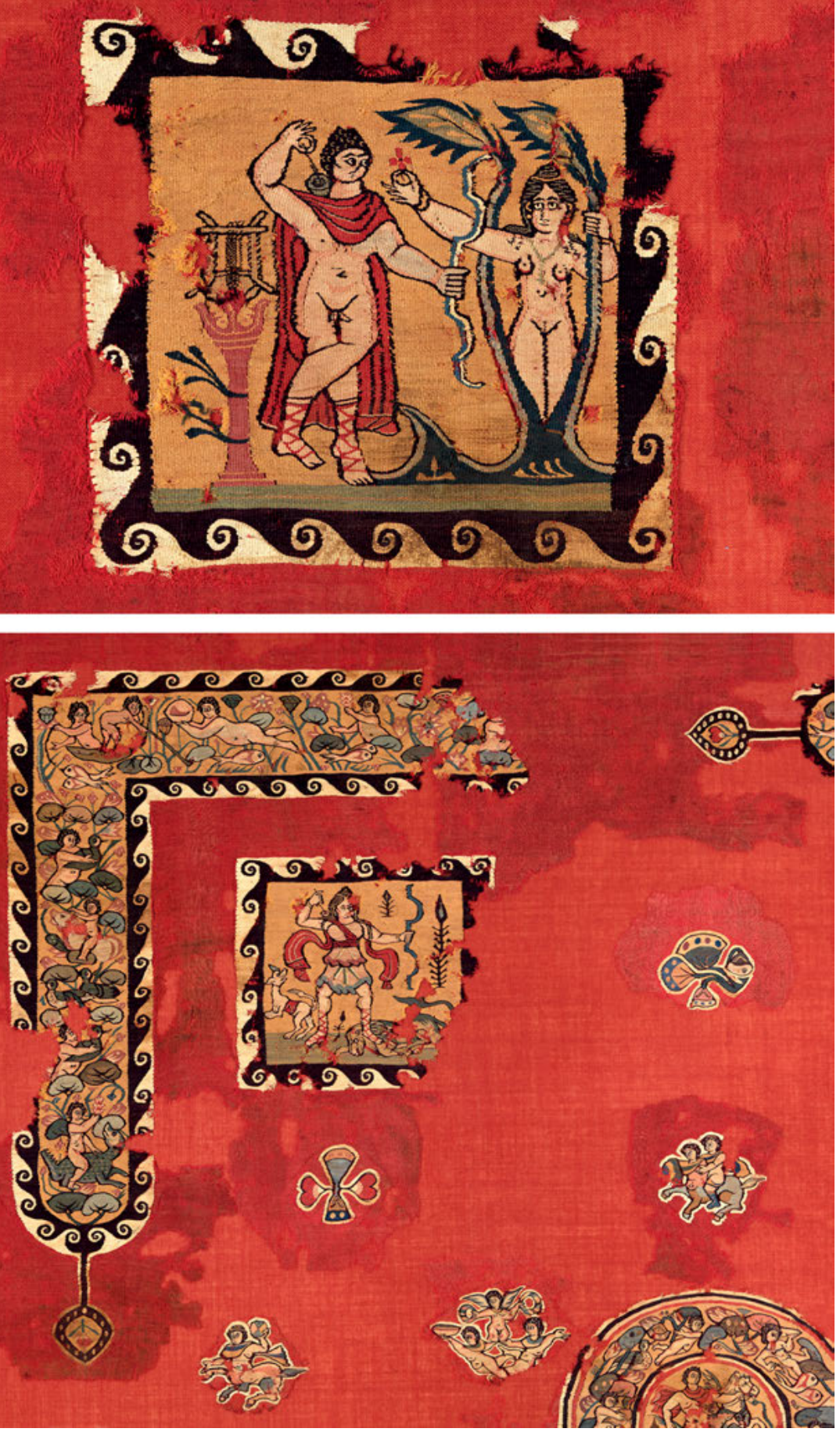

Fig. 19a-b: Depictions of Apollo, Daphne and Artemis on the "Shawl of Sabina" (๔ Musée du Louvre/Georges Poncet). 


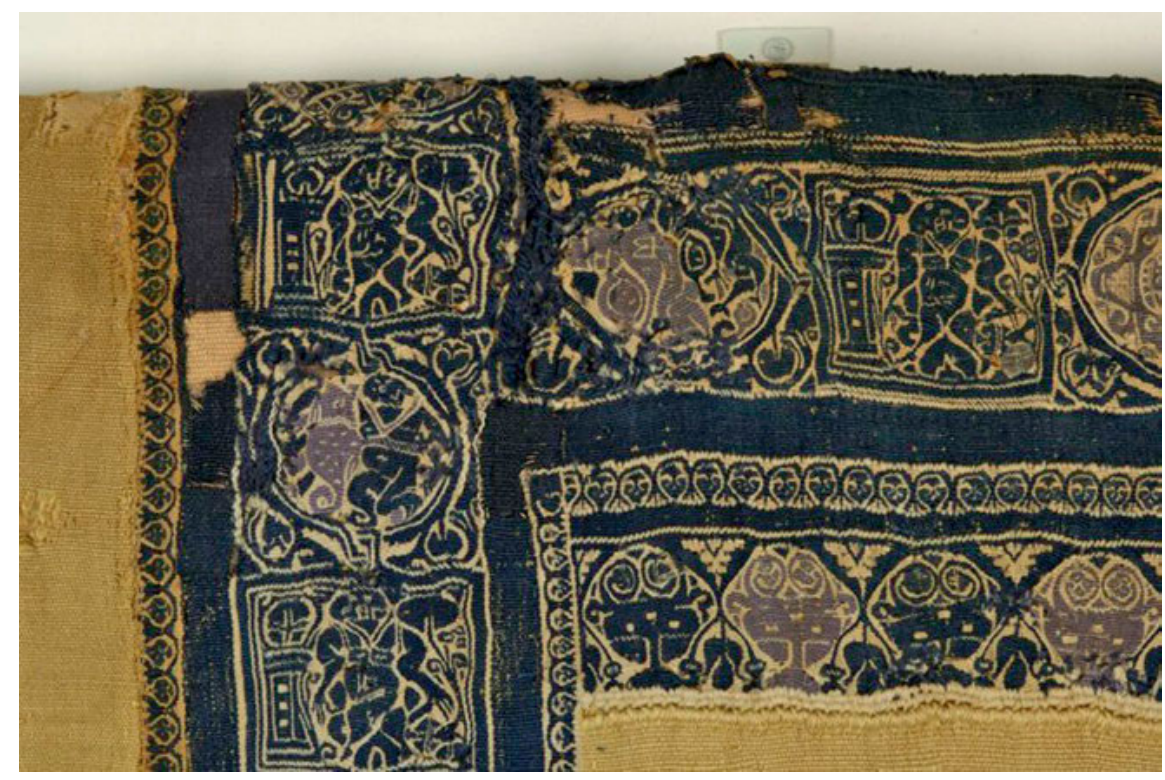

Fig. 20: Coptic wool tunic with mythological motifs, $7^{\text {th }}$ century, wool, $131.9 \times 190.5 \mathrm{~cm}$, Brooklyn Museum, Charles Edwin Wilbour Fund, acc. no. 41.523 (Brooklyn Museum photograph 2007). 